\title{
Neogene kinematics of the Giudicarie Belt and eastern Southern Alpine orogenic front (northern Italy)
}

\author{
Vincent F. Verwater ${ }^{1}$, Eline Le Breton ${ }^{1}$, Mark R. Handy ${ }^{1}$, Vincenzo Picotti ${ }^{2}$, Azam Jozi Najafabadi ${ }^{3}$, and \\ Christian Haberland $^{3}$ \\ ${ }^{1}$ Institut für Geologische Wissenschaften, Freie Universität, Berlin, Germany \\ ${ }^{2}$ Department of Earth Sciences, ETH-Zürich, Zürich, Switzerland \\ ${ }^{3}$ German Research Centre for Geosciences, GFZ, Potsdam, Germany
}

Correspondence: Vincent F. Verwater (vincent.verwater@fu-berlin.de)

Received: 24 February 2021 - Discussion started: 1 March 2021

Revised: 11 May 2021 - Accepted: 12 May 2021 - Published: 15 June 2021

\begin{abstract}
Neogene indentation of the Adriatic plate into Europe led to major modifications of the Alpine orogenic structures and style of deformation in the Eastern and Southern Alps. The Giudicarie Belt is a prime example of this, as it offsets the entire Alpine orogenic edifice; its activity has been kinematically linked to strike-slip faulting and lateral extrusion of the Eastern Alps. Remaining questions on the exact role of this fold-and-thrust belt in the structure of the Alpine orogen at depth necessitate a quantitative analysis of the shortening, kinematics, and depth of decoupling beneath the Giudicarie Belt and adjacent parts of the Southern Alps. Tectonic balancing of a network of seven cross sections through the Giudicarie Belt parallel to the local NNW-SSE shortening direction reveals that this belt comprises two kinematic domains that accommodated different amounts of shortening during overlapping times. These two domains are separated by the NW-SE-oriented strike-slip Trento-Cles-SchioVicenza fault system, which offsets the Southern Alpine orogenic front in the south and merges with the Northern Giudicarie Fault in the north. The SW kinematic domain (Val Trompia sector) accommodated at least $\sim 18 \mathrm{~km}$ of Late Oligocene to Early Miocene shortening. Since the Middle Miocene, this domain experienced at least $\sim 12-22 \mathrm{~km}$ shortening, whereas the NE kinematic domain accommodated at least $\sim 25-35 \mathrm{~km}$ shortening. Together, these domains contributed an estimated minimum of $\sim 40-47 \mathrm{~km}$ of sinistral strike-slip motion along the Northern Giudicarie Fault, implying that most offset of the Periadriatic Fault is due to Late Oligocene to Neogene indentation of the Adriatic plate into the Eastern Alps. Moreover, the faults linking the Giudicarie
\end{abstract}

Belt with the Northern Giudicarie Fault reach $\sim 15-20 \mathrm{~km}$ depth, indicating a thick-skinned tectonic style of deformation. These fault detachments may also connect at depth with a lower crustal Adriatic wedge that protruded north of the Periadriatic Fault and are responsible for $\mathrm{N}-\mathrm{S}$ shortening and eastward, orogen-parallel escape of deeply exhumed units in the Tauern Window. Finally, the E-W lateral variation of shortening across the Giudicarie Belt indicates internal deformation and lateral variation in strength of the Adriatic indenter related to Permian-Mesozoic tectonic structures and paleogeographic zones.

\section{Introduction}

The fold-and-thrust belt of the eastern Southern Alps formed due to indentation of the Adriatic plate into the Eastern Alps (Schönborn, 1992, 1999; Picotti et al., 1995; Frisch et al., 1998, 2000; Castellarin and Cantelli, 2000; Linzer et al., 2002; Rosenberg et al., 2007; Pomella et al., 2011, 2012; Favaro et al., 2017). Indentation is defined as the postcollisional penetration of a relatively stiff part of an upper plate into a weaker, already existing orogenic edifice (e.g. Tapponier et al., 1986). In the Alps, indentation modified the early Tertiary nappe structure of the orogen (Schmid et al., 2004), including post-nappe folding and exhumation of Alpine metamorphic units in the Tauern Window (Rosenberg et al., 2018), eastward lateral extrusion of the Austroalpine nappes (Ratschbacher et al., 1991; Rosenberg et al., 2007; Scharf et al., 2013), and south-directed folding in 
the Southern Alps (Doglioni and Bosellini, 1987; Castellarin et al., 2006b). The Giudicarie Fault, subdivided into northern (NGF) and a southern (SGF) branches, is a prominent structure that sinistrally offsets the Periadriatic Fault (PF) by $\sim 75 \mathrm{~km}$ in map view (Fig. 1). It ends to the north at the western boundary of Neogene post-nappe folding of the Tauern Window and lateral escape of the Eastern Alps (Frisch et al., 2000; Linzer et al., 2002; Scharf et al., 2013). Previous studies have established a direct kinematic link between sinistral motion along the NGF and Neogene exhumation in the Tauern Window (Ratschbacher et al., 1989; Frisch et al., 1998, 2000; Linzer et al., 2002; Rosenberg et al., 2007; Scharf et al., 2013; Schmid et al., 2013; Handy et al., 2015; Favaro et al., 2015, 2017; Hülscher et al., 2021). This complex response of the orogenic crust to indentation calls for detachment of both sedimentary cover and metamorphic units above one or more detachments located at or above the Moho Discontinuity (Oldow et al., 1990). To the south, the Giudicarie fold-and-thrust belt trends obliquely to the dominantly south-verging thrusts in the Southern Alps and consists of (1) N-S-to-NNE-SSW-trending thrusts and strike-slip faults and (2) E-W-trending thrusts (e.g. the Valsugana Fault and Southern Alps orogenic front; Fig. 1). The question arises as to how oblique sinistral shortening accommodated by the Giudicarie Belt is linked to Neogene displacements on the Giudicarie Fault, the Periadriatic Fault, and in the Tauern Window. In particular, the kinematic link of this belt to the northern and southern segments of the Giudicarie Fault remains poorly constrained and is the focus of this study.

The Giudicarie Fault also coincides with significant changes in the mantle structure, as imaged by tomographic P-wave models that show a SE-dipping slab anomaly beneath the Central Alps and a steeply dipping enigmatic slab anomaly beneath the Eastern Alps (Lippitsch et al., 2003; Mitterbauer et al., 2011; Karousová et al., 2012). The model of Lippitsch et al. (2003) shows that the slab anomaly beneath the Eastern Alps dips towards the NNE, which would suggest a subduction of the Adriatic plate, with a length varying from $50 \mathrm{~km}$ in the west to $210 \mathrm{~km}$ in the east. However, the exact dip, length, and plate tectonic affinity (Adriatic, European, or mixed) of this slab anomaly remains under strong debate (Mitterbauer et al., 2011; Handy et al., 2015; Qorbani et al., 2015; Kästle et al., 2020). Any amount of Adriatic subduction should be reflected in both Neogene shortening estimates across the eastern Southern Alps and Neogene estimates of lateral extrusion of the Eastern Alps. Proposed estimates for the amount of shortening across the Giudicarie Belt and Southern Alps range from 30 to $100 \mathrm{~km}$ (Laubscher, 1990; Doglioni, 1992; Roeder, 1992; Schönborn, 1992, 1999; Picotti et al., 1995; Castellarin and Cantelli, 2000; Nussbaum, 2000). This wide range reflects the complexity in the kinematics and strain partitioning between thrusts and strikeslip faults within the Giudicarie Belt. Therefore, this study aims to provide new constraints on the kinematics of shortening within the Giudicarie Belt, as well as on the depth of deformation within the Adriatic indenter, to discuss its relationships to Neogene exhumation in the Tauern Window and lateral extrusion in the Eastern Alps. To do so, we first review the Permian to Jurassic pre-existing structures and paleogeography of the eastern Southern Alps that affect the kinematics and partitioning of the deformation related to the Alpine Orogeny (Sect. 2). Structural observations on the field (Sect. 3) and deformation ages (Sect. 4) along the Giudicarie belt are then used to construct a series of balanced geological cross sections (Sect. 5). Based on the calculated amount of shortening, we propose a kinematic sub-division of the Giudicarie Belt (Sect. 6) and discuss the relationship between Neogene shortening along the Giudicarie Belt and Neogene motion along the NGF, a topic which has fascinated many researchers in the past (Castellarin and Vai, 1981; Picotti et al., 1995; Prosser, 1998, 2000; Müller et al., 2001; Viola et al., 2001; Linzer et al., 2002; Stipp et al., 2004; Pomella et al., 2011, 2012).

\section{Geological setting}

\subsection{The eastern Southern Alps}

The Southern Alps are a predominantly south-vergent foldand-thrust belt, at the leading edge of the Adriatic plate indenting the European plate to the north. The Giudicarie Fault is the boundary between eastern and western parts of the Southern Alps (Schönborn, 1999; Castellarin and Cantelli, 2000). In the Late Cretaceous, the tectonic regime shifted in the Alps from $\mathrm{E}-\mathrm{W}$ extension to $\mathrm{N}-\mathrm{S}$ shortening due to convergence between Adria and Europe (e.g. Dewey et al., 1989). The western Southern Alps record a Late Cretaceous compressional phase (documented by the so-called Lombardian Flysch, e.g. Doglioni and Bosellini, 1987; Bernoulli and Winkler, 1990; as well as thrusting that pre-dates the Paleogene Adamello intrusive body; see Brack, 1981) followed by Oligocene to Middle Miocene shortening (e.g. Schönborn, 1992; Schmid et al., 1996). Only the western Southern Alps have recorded this Late Cretaceous deformation (Castellarin et al., 1992), as within the eastern Southern Alps evidence of this phase is lacking. The eastern Southern Alps comprise actively accreting cover units of the Adriatic plate and are bounded to the north by the PF, to the west by the NGF and SGF, to the east by Dinaric thrusts and active strikeslip faults, and to the south by the Po Plain (Fig. 1). Paleostress analyses (Castellarin et al., 1992; Castellarin and Cantelli, 2000; Zampieri et al., 2003) and structural analysis of the NGF (Prosser, 1998, 2000; Viola et al., 2001) show that during the Middle to Late Miocene, the eastern Southern Alps were dominantly affected by NNW-SSE shortening, which reactivated many Permo-Jurassic faults. This Neogene NNW-SSE shortening was preceded by a minor phase of Eocene E-W extension related to the opening of a volcanic 


\section{a}

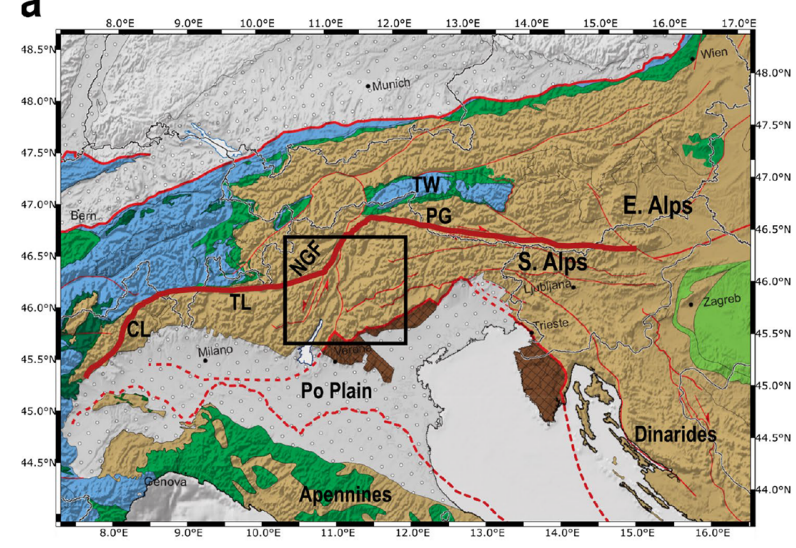

Tectonic units Figure 1a

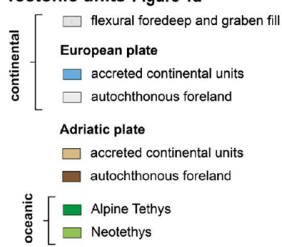

Chronostratigraphy Figure 1b

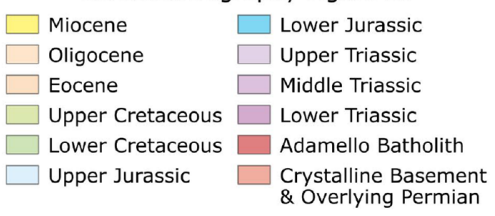

$11.5^{\circ} \mathrm{E}-12.0^{\circ} \mathrm{E}$

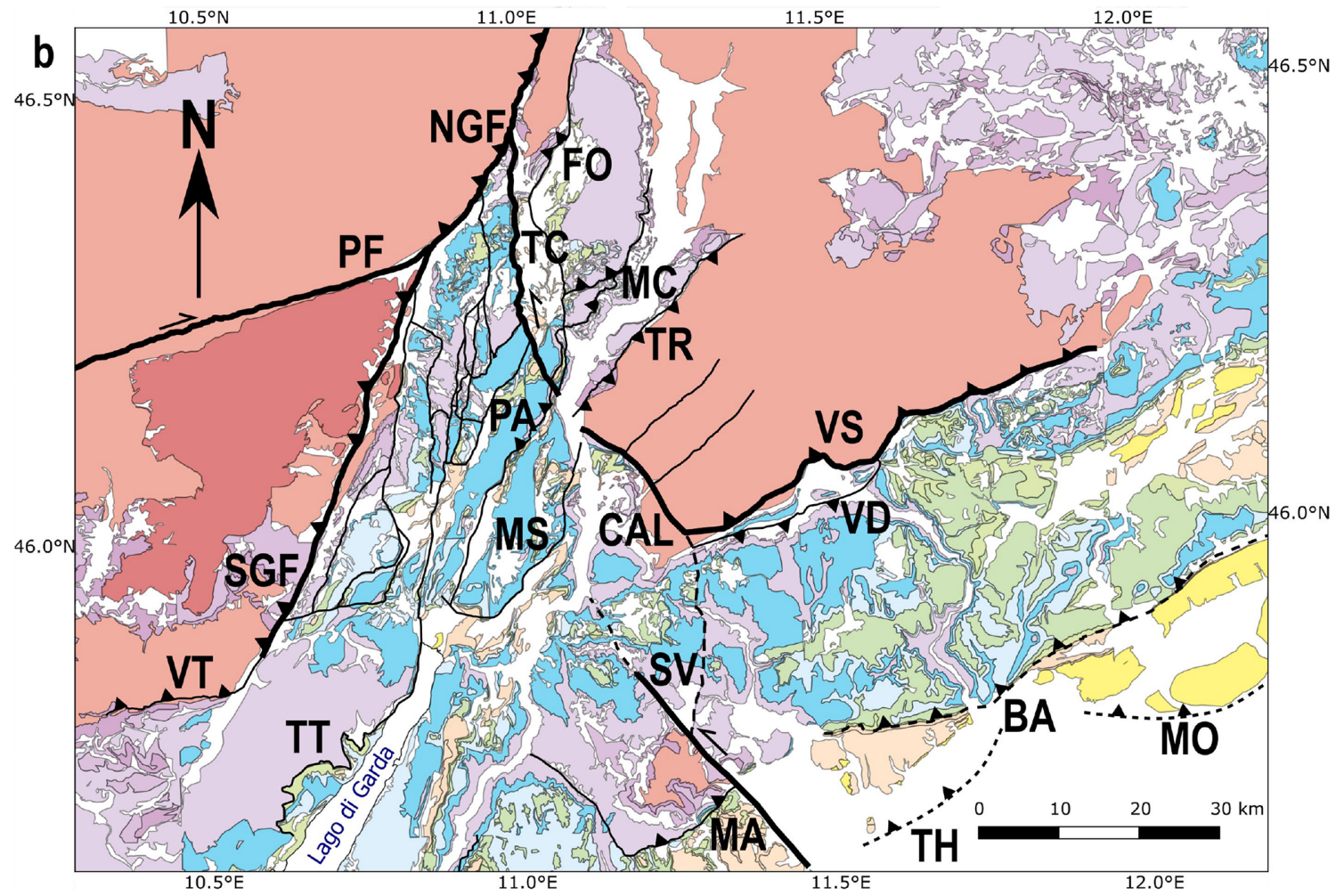

Figure 1. (a) Tectonic provenance map of the Alps (Handy et al., 2010 simplified from Schmid et al., 2004, 2008). The Southern Alps and Dinarides are accreted units derived from the Adriatic plate (brown). The Southern Alps are bounded to the north by the Periadriatic Fault (PF), which is sinistrally offset by the Northern Giudicarie Fault (NGF). The PF is divided into a western segment (Tonale and Canavese Lines, TL and CL, respectively) and eastern segment (Pusteria-Gailtal Line, PG). (b) Geological map of our study area (Giudicarie Belt) in the eastern Southern Alps indicated by a black square in (a) (TW is the Tauern Window). Fault abbreviations are as follows: BA stands for Bassano, CAL stands for Calisio, FO stands for Foiana, MA stands for Marana, MC stands for Mezzocorona, MO stands for Montello, MS stands for Monte Stivo, PA stands for Paganella, SGF stands for Southern Giudicarie, SV stands for Schio-Vicenza, TC stands for TrentoCles, TH stands for Thiene-Bassano, TR stands for Truden, TT stands for Tremosine-Tignale, VD stands for Val di Sella, VS stands for Valsugana, and VT stands for Val Trompia.

graben, which was only recorded locally in the southernmost part of the Trento Platform (Zampieri, 1995).

Directly north of the Giudicarie Belt and Periadriatic Fault, nappes in the Tauern Window were affected by kilometre-scale upright folding and orogen-parallel extrusion towards the Pannonian Basin in Miocene time (Ratschbacher et al., 1991; Frisch et al., 1998; Scharf et al., 2013). The northern Alpine front west of Munich (northwest of the Tauern Window) was active until the Pliocene (Von Hagke et al., 2012), whereas east of Munich it ceased propagating northwards after $\sim 20$ to $15 \mathrm{Ma}$ (Ortner et al., 2015). This cessation coincides broadly with the onset of sinistral trans- 
pression along the Giudicarie Belt, as well as south-directed thrusting in the eastern Southern Alps (Castellarin and Cantelli, 2000; Schmid et al., 2013, and references therein). During this time, rapid exhumation of Penninic and Subpenninic nappes in the Tauern Window commenced (Fügenschuh et al., 1997), although slower exhumation in the Tauern Window may already have started earlier, in the late Oligocene time (Pomella et al., 2012; Scharf et al., 2013; Favaro et al., 2015). Taken together, these events have been interpreted to indicate that Adriatic indentation triggered the orogenparallel extrusion of the Eastern Alps towards the Pannonian Basin (Ratschbacher et al., 1989; Frisch et al., 1998, 2000; Linzer et al., 2002; Rosenberg et al., 2007; Favaro et al., 2017). Contrasting estimates have been proposed for the amount of lateral extrusion, ranging from 14-62 km (Rosenberg and Garcia, 2011; disputed by Fügenschuh et al., 2012), 65-77 km (Favaro et al., 2017), $100 \mathrm{~km}$ (Scharf et al., 2013), to as much as $120 \mathrm{~km}$ (Linzer et al., 2002) and $160 \mathrm{~km}$ (Frisch et al., 2000).

The NGF and its northern prolongation, the Meran Mauls Fault, sinistrally offset the PF by $75 \mathrm{~km}$, dividing the PF into the Tonale Line (western segment) and the PusteriaGailtal Line (eastern segment; Fig. 1). Discussion has focused on whether the NGF is an exclusively Neogene fault that sinistrally offsets a formerly straight PF, or if the NGF formed a pre-Neogene bend of the PF that was reactivated under transpression during the Neogene (Castellarin and Vai, 1981; Picotti et al., 1995; Prosser, 1998, 2000; Müller et al., 2001; Viola et al., 2001; Linzer et al., 2002; Stipp et al., 2004; Pomella et al., 2011, 2012). The latter hypothesis is supported by Picotti et al. (1995), who estimated that the amount of strike-slip (30-40 km) along the NGF, extrapolated from the amount of Neogene shortening calculated within the southwestern part of the Giudicarie Belt, was less than the $75 \mathrm{~km}$ offset of the PF. In addition, several studies (e.g. Doglioni and Bosellini, 1987; Castellarin et al., 2006b) have interpreted the lateral termination of the Cretaceous pre-Adamello deformation phase along the NGF, as a late Cretaceous lateral ramp. However, the interpretation of a pre-Neogene offset PF is incompatible with the proposed 100-150 km of Paleogene dextral strike-slip along this fault (Laubscher, 1991; Schmid and Kissling, 2000) based on offset correlative features on either side of it, i.e. the Ivrea and Pejo zones (Laubscher, 1991) and the Sesia-Dent Blanche and Margna units (Laubscher 1991; Schmid et al., 1996; Handy et al., 2005). In addition, a paleomagnetic study of Pomella et al. (2011) convincingly shows that the Periadriatic granitoid intrusions along the NGF underwent anticlockwise rigid-body rotation into their current NNE-SSWstriking orientation in Neogene time, suggesting the NGF can be interpreted as a rotated segment of the PF (Pomella et al., 2011, 2012). A paleomagnetic study across the Southern and Eastern Alps possibly indicates a larger-scale coherent Oligocene to Miocene rotation rather than a local reorientation (Thöny et al., 2006). Potential links between Neo- gene shortening in the Giudicarie Belt and strike-slip motion across the NGF and adjacent Tonale and Pusteria-Gailtal fault segments are therefore of great relevance for a better understanding of Neogene collision processes in the Eastern and Southern Alps.

To assess the amount of Neogene shortening within the eastern Southern Alps, it is important to constrain the role of inherited Permian to Mesozoic structures. Indeed, many of the Neogene fault structures were inherited from earlier tectonic events, which include Permian to Jurassic rifting phases (Handy, 1987; Handy and Zingg, 1991; Bertotti et al., 1993; Selli et al., 1996; Picotti and Cobianchi, 2017; Le Breton et al., 2021).

\subsection{Permian to Jurassic paleogeography}

Based on Permo-Mesozoic stratigraphic variations, we divide our study area into six different paleogeographical zones (Fig. 2) which, as we show below, exert important controls on the partitioning of Neogene shortening. Within the eastern Southern Alps, the Atesina Volcanic Complex (Fig. 2) is a good example of a Permian basin filled with volcanic sediments, with the Valsugana Fault interpreted as a dextral Permian feature (Zampieri et al., 2003) and the Calisio and Truden faults recording a Permian normal faulting history (Selli et al., 1996). Another minor unit in the eastern Southern Alps containing evidence of this interpreted Permian transtensional phase (Zampieri et al., 2003) is exposed in the hanging wall of the Foiana Fault (Fig. 1).

From the Late Triassic to Jurassic, a rifting related to the opening of the Alpine Tethys west and north of Adria (Piemont-Liguria Ocean) affected the Adriatic plate (e.g. Handy, 1987; Handy and Zingg, 1991; Bertotti et al., 1993; Picotti and Cobianchi, 2017; Le Breton et al., 2021). The rifting of Alpine Tethys led to the formation of carbonate platforms and basins bounded by $\mathrm{N}-\mathrm{S}$-trending faults that are still well preserved within the Southern Alps (Bernoulli and Jenkyns, 1974; Winterer and Bosellini, 1981). The main NS-trending faults divided the area into four different zones from west to east (Bernoulli and Jenkyns, 1974; Winterer and Bosellini, 1981): the Lombardian Basin, the Trento Platform, the Belluno Basin, and the Friuli Platform (Fig. 2). The Lombardian Basin recorded the most Triassic to Jurassic subsidence (Winterer and Bosellini, 1981; Bertotti et al., 1993), reaching $\sim 5 \mathrm{~km}$ of sedimentary thickness, and is bounded in the east by the Ballino-Garda and Tremosine-Tignale Faults (Figs. 1 and 2). Differential subsidence caused significant stratigraphic thickness variations within the Jurassic paleogeographic zones (Picotti et al., 1995). Within the Trento Platform, thicknesses decrease from $\sim 3$ to $\sim 2 \mathrm{~km}$ both towards the SE and NE, dividing the Trento Platform itself into sub-zones: the Trento Platform (numbered 2 on Fig. 2), the Reduced Recoaro High (2a), the Reduced Trento Platform (2b), the Atesina Volcanic Complex (2c), and the Asiago Plateau (2d). These thickness variations broadly coincide 


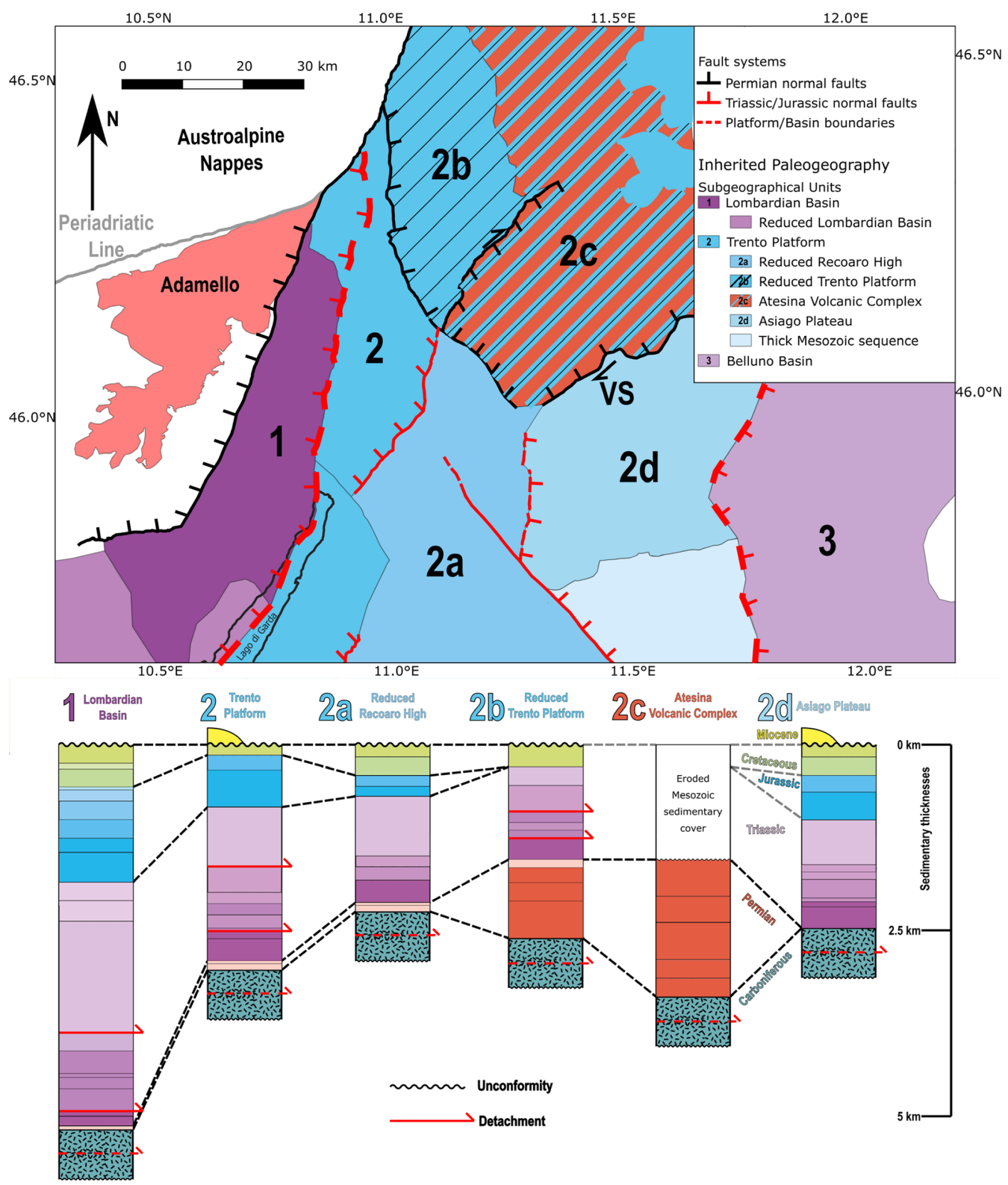

Figure 2. Triassic to Jurassic paleographic basinal (1, Lombardian Basin; in violet) and platform zones (2, Trento Platform in blue). Based on Mesozoic thickness variations, the Trento Platform is subdivided into units $2 \mathrm{a}-\mathrm{d}$. Note that within zone $2 \mathrm{c}$ no Mesozoic sediments are exposed and the thickness of the eroded Mesozoic sequence is extrapolated from zone $2 \mathrm{~b}$, based on the occurrence of Miocene conglomerates with Mesozoic clasts unconformably overlying Mesozoic strata in zone 2d. Zone 2 also includes a Cenozoic sequence unconformably overlying Mesozoic strata outcropping at Monte Brione (see discussion Sect. 4). Simplified stratigraphic columns (lower panel) for each paleogeographic zone 1-2 d.

with Neogene faults, including the Trento-Cles Fault, Truden Fault, Calisio Fault, Valsugana Fault, and Schio-Vicenza Fault (Figs. 1 and 2). The Atesina Volcanic Complex forms the most prominent Permian paleogeographical zone with a $2 \mathrm{~km}$ thick Permian sequence, with no overlying Triassic to Cretaceous sedimentary cover outcropping (Fig. 2). It is assumed that the Atesina Volcanic Complex (zone 2c) had a similar Mesozoic cover to the nearby and paleogeo- graphically comparable Reduced Trento Platform (2b) (Selli, 1998), which was later eroded in the Miocene. This assumption is based on the observation of Mesozoic clasts found in Miocene conglomerates in the footwall of the Valsugana Fault (Castellarin et al., 1992). Another paleogeographic zone containing thinner Permian volcanic successions (up to $\sim 1 \mathrm{~km}$ thick; Fig. 2) is the Reduced Trento Platform. Further small-scale thickness variations across Mesozoic faults occur 
within the paleogeographic zones defined here (Franceschi et al., 2014). However, these are beyond the aim of this paper and are neglected in order to simplify the construction and balancing of cross sections (Sect. 5).

\section{Structural observations and fault-slip analysis}

Structural data from the eastern Southern Alps were collected as input for fault-slip analysis to calculate the main Neogene shortening direction. This was necessary to estimate the amount of shortening parallel to the shortening direction in the balanced cross sections. Special attention was paid to fault systems coinciding with paleographic variations (the Trento-Cles, Calisio, Valsugana, and Schio-Vicenza Faults; Figs. 1, 2, 3 and 4) to test if these features coincide with variations in structural style and amount of shortening.

Structural analysis in the Giudicarie-Valsugana sector of the eastern Southern Alps included measuring fault surfaces, their striations and shear-sense, fold-axial planes, and bedding planes near folds and faults. These data formed the input for fault-slip analysis, which was performed in the WinTensor software version 5.8.8 (Delvaux and Sperner, 2003). An angle of $30^{\circ}$ between the maximum principal stress and the shear plane based on the Mohr-Coulomb failure criterion was assumed. However, given the proximity of the measured fault striations to major fault structures (Fig. 4), this angle might have been different due to strain complexities. The maximum principal stress $1 \sigma$ was calculated in the WinTensor software for various fault systems, assuming that structures measured in the field reflect the principal incremental strain direction and principal stress direction $1 \sigma$. The final stereoplots with results of the fault-slip analysis calculated with WinTensor were drawn using FaultKin 8.0.0 software (Fig. 4; Marrett and Allmendinger, 1990).

Bedding and striation measurements (Fig. 3) were collected along the Bassano (Fig. 3a) and Marana (Fig. 3b) thrust faults on either side of the Schio-Vicenza Fault (Fig. 3c, d and e) to test for variations in structural style. The Schio-Vicenza Fault represents an inherited Mesozoic feature associated with stratigraphic thickness variations (Fig. 2). Along the Borcola Pass Fault zone, a branch of the Schio-Vicenza Fault, steeply dipping NW-SE-to-NS-trending fault surfaces containing sinistral striations cut Eocene mafic dikes (Fig. 3c and d). Striation steps indicating sinistral motion related to local NNW-SSE incremental strain (Fig. 3d) parallel to the main shortening direction (Castellarin and Cantelli, 2000) indicate that the SchioVicenza Fault was reactivated during post-Eocene time. These striations are overprinted by younger striations indicating downthrow of the NE block (Fig. 3e) that are interpreted to be related to flexural extension of the foreland bulge of the Apennines (Pola et al., 2014). Contrasting deformation styles east and west of the fault may indicate that the Schio-Vicenza Fault acted as a transfer fault. Indeed, directly east of the Schio-Vicenza Fault, strata in the hanging wall of the Bassano Fault (Fig. 1) are steeply dipping, strongly folded, and form the forelimb of the ENE-WSW-trending Monte Grappa ramp anticline (Fig. 3a), whereas to the west, the Marana thrust emplaces cataclastically deformed Norian Dolomia Principale on Hettangian to Pliensbachian Calcari Grigi (Fig. 3b). We note that in the hanging wall of the Marana thrust, a deeper structural level is exposed than in the hanging wall of the Bassano Fault, implying that the observed variation in structural style may partly be due to a different erosional level. Variability in the geometry at depth of the Bassano and Marana Faults (see discussion in Sect. 5.2) are the cause of the observed contrasting structural styles. The deeper level of exposure along the Marana thrust and the southern part of zone 2a (Fig. 2) has been interpreted to indicate that this area represents a structural high (prolongation of the Adige embayment in Laubscher, 1990). No thrust associated with the Monte Grappa ramp anticline is exposed; the anticline is therefore interpreted as a fault-propagation fold above the blind Bassano Fault, in agreement with earlier studies (Doglioni, 1990; Roeder, 1992; Pilli et al., 2012; Pola et al., 2015). The Schio-Vicenza Fault is only observed as far north as the Adige Valley. However, previous studies argued for either a continuous Trento-Cles-Schio-Vicenza (TC-SV) fault system (Semenza, 1974) or a contractional strike-slip step-over, with the Calisio Fault connecting the Trento-Cles and Schio-Vicenza Faults (Zampieri et al., 2003, 2021). The TC-SV fault system will be further discussed in Sects. 5 and 6.

Strike-slip deformation along the Schio-Vicenza Fault ends towards the NW in the vicinity of the Valsugana Fault (Fig. 1). This fault was reactivated as a Neogene thrust and emplaced Variscan basement onto Mesozoic sediments of the Trento Platform in its western part and Triassic onto Jurassic strata in the east. Striations in the field measured along faults conjugate to the main trend of the Valsugana show thrust motion with components of dextral (Fig. 3f) and sinistral strikeslip. Fault-slip analysis on these striations (Fig. 4) is consistent with NNW-SSE shortening, exactly perpendicular to the main Valsugana Fault trend. Therefore, we interpret that there was no significant component of Neogene strike-slip motion along the Valsugana Fault. The lateral ramp of the Valsugana Fault is the Calisio Fault (Fig. 1), which merges with the Trento-Cles Fault, thereby inverting a major Permian paleographic boundary (Fig. 2). Striations from the Valsugana, Marana, Bassano, and Schio-Vicenza faults; ENEWSW-trending axial planes and axes of the Monte Grappa ramp anticline; and striations in the footwall of the Marana Fault and results from a literature compilation (Fig. 4) are all consistent with NNW-SSE shortening. 

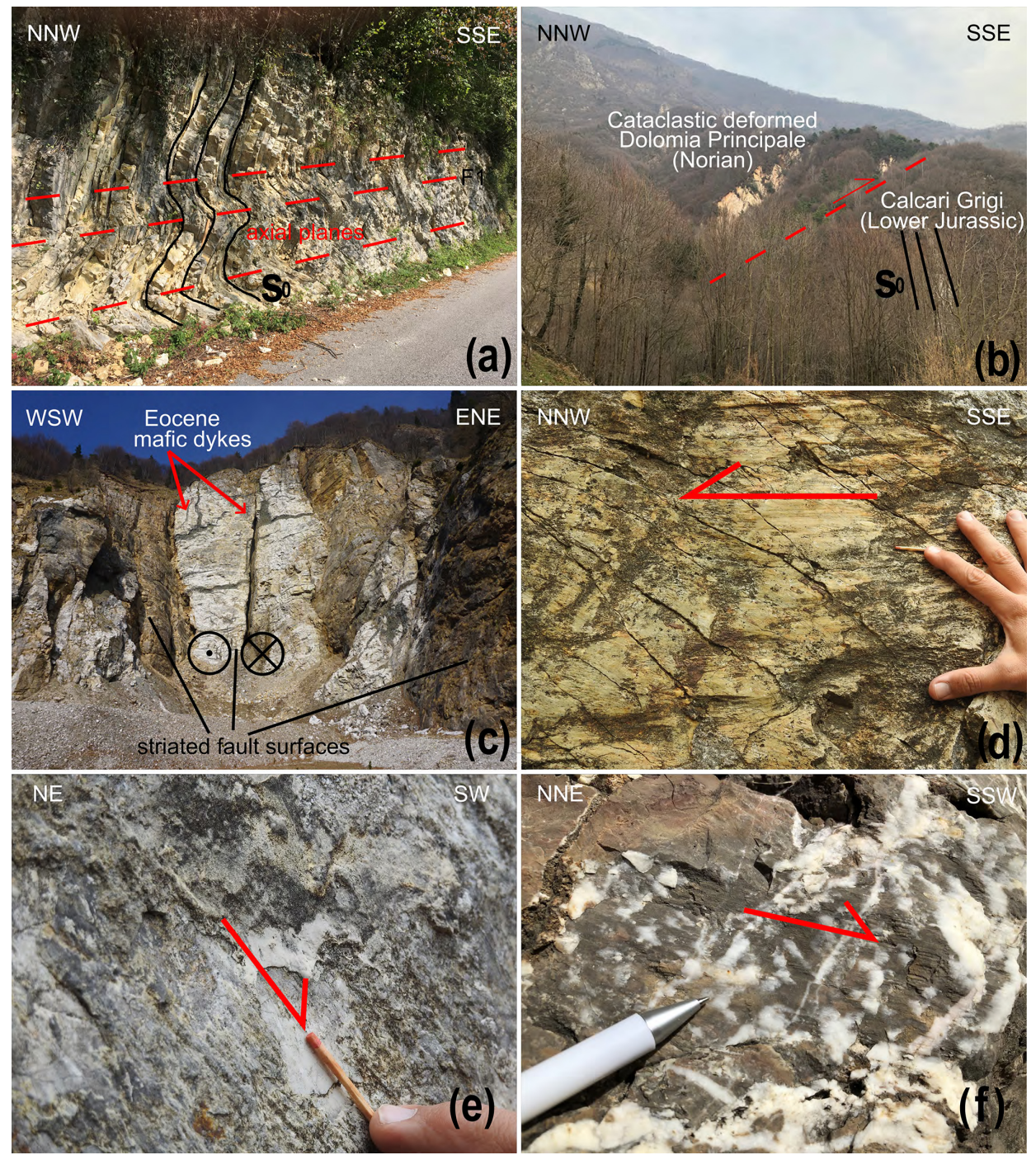

Figure 3. (a) Steepened Lower Cretaceous strata (Majolica), which are commonly found in the forelimb of the Monte Grappa ramp anticline forming the hanging wall of the blind Bassano Thrust. The dashed black lines indicate axial planes of chevron folds (formed due to flexural slip). (b) The Marana Thrust at Zanconati emplaces Norian Dolomia Principale on Lower Jurassic Calcari Grigi. (c) The Schio-Vicenza Fault at Passo della Borcola, offsetting Norian Dolomia Principale and Eocene mafic dykes. Striations on fault surfaces indicate oblique sinistral down-dip motion. (d) Older striations on the Borcola Pass Fault Zone (BPFZ; after Fondriest et al., 2012) indicating a sinistral sense of motion. (e) Younger striations on the BPFZ indicating oblique downthrow of the NE block of the BPFZ. (f) Dextral strike-slip slickenfibres at the eastern end of the hanging wall of the Valsugana Fault (near Pieve di Cadore) where the Valsugana Fault branches into several fault splays and becomes transpressive. The uninterpreted field photographs can be found in Verwater et al. (2021).

\section{Age of deformation in the eastern Southern Alps}

Individual thermochronological dated faults within the eastern Southern Alps include the NGF, SGF, Valsugana, and Val Trompia faults, which are broadly coeval with stratigraphic age constraints indicating Neogene deformation (Fig. 5). Deformation in the eastern Southern Alps initiated during late Oligocene time (27.8-23.0 Ma), indicated by a detailed seismic survey beneath the Po Plain that documented Chattian to Burdigalian deposits affected by Late Oligocene to Neogene thrusts sealed by Messinian strata (e.g. Fantoni and Franciosi, 2010, and references therein).

A maximum age for the onset of thrusting within the Giudicarie Belt itself is given by the youngest sediments below a thrust that accommodated NNW-SSE shortening. At Monte Brione, at the northern end of Lake Garda (Fig. 1), the base of an arenitic-pelitic sequence dated at $21.5 \mathrm{Ma}$ (Luciani and Silvestrini, 1996) shows westward divergent on-laps suggestive of growth in a footwall syncline (Castellarin et al., 2005). Directly east of Monte Brione, similar stratigraphic age constraints are found within deformed sed- 

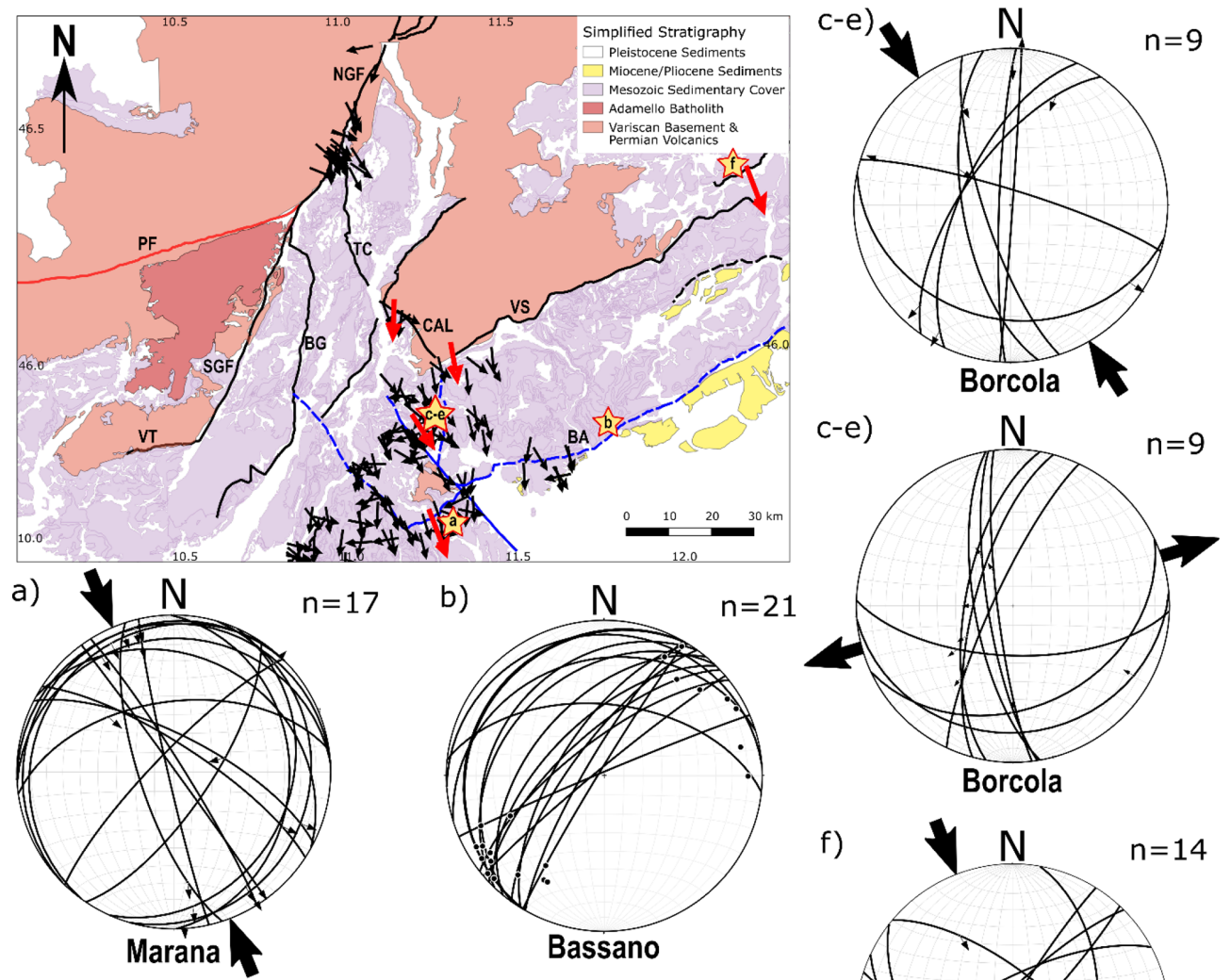

f)

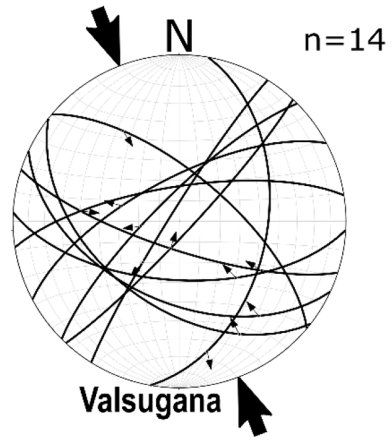

Figure 4. Structural map of the eastern Southern Alps showing the distribution of fault slip data from this study (in red; locations a-e indicated by stars on the map) and from the literature (in black). The geological map is a compilation of own field data and published geological maps (Bartolomei et al., 1969; Bosellini et al., 1969; Castellarin et al., 1968, 2005; Braga et al., 1971; Dal Piaz et al., 2007; Avanzini et al., 2010). See Fig. 1 for fault abbreviations. The field data include fold axes plotted on their fold axial planes for the Bassano Fault (b) and fault-slip analyses with local paleostrain directions for the Marana (a), Valsugana (f), and Borcola (c-e) faults. Two distinct stereoplots are shown for Borcola as two generations of striations are observed here (see discussion in Sect. 3). Regional (Castellarin and Cantelli, 2000; Zampieri et al., 2003) and local (Prosser, 1998, 2000; Viola et al., 2001) paleostrain analyses from the literature are indicated in black. The data indicate a dominant NNW-SSE shortening direction.

iments of 28-16 Ma in the footwall of the Monte Stivo thrust (Fig. 5). Yet further to the east in the footwall of the Valsugana Fault, deformed Serravallian ( 14-12 Ma) sediments date south-directed thrusting (Castellarin et al., 1992; Selli, 1998). Similar ages (17-9 Ma) were obtained with apatite fission tracks from the hanging wall of the Valsugana Fault and several faults along the Giudicarie Belt (Pomella et al., 2012; Heberer et al., 2016). This main phase of Neogene shortening has been termed the Valsugana Phase and was coeval with shortening along the Giudicarie Belt (Castellarin et al., 1992; Castellarin and Cantelli, 2000). Several former Mesozoic structures were reactivated during the Valsugana phase, including the Schio-Vicenza Fault (Fig. 2). The final pulse of exhumation of the Valsugana phase occurred between 10 and $8 \mathrm{Ma}$, as shown by a study of Reverman et al. (2012) using (U-Th-Sm)/He and fission track thermochronology on apatites from the Adamello batholith.

A younger phase of Messinian to Pliocene shortening has been recognized along the Bassano and Montello faults of the Southern Alpine orogenic front (Massari et al., 1986; Castellarin et al., 1992). Late Tortonian to Early Pliocene fossils (Dal Piaz, 1912; Massari et al., 1986) are found in mudstones interbedded with conglomerates in a syn-tectonic wedge in the hanging wall of the Bassano and Montello Faults (Massari et al., 1986). Historical seismicity (e.g. Galadini et al., 2005) and clustering of (micro-)seismic hypocentres (Ro- 


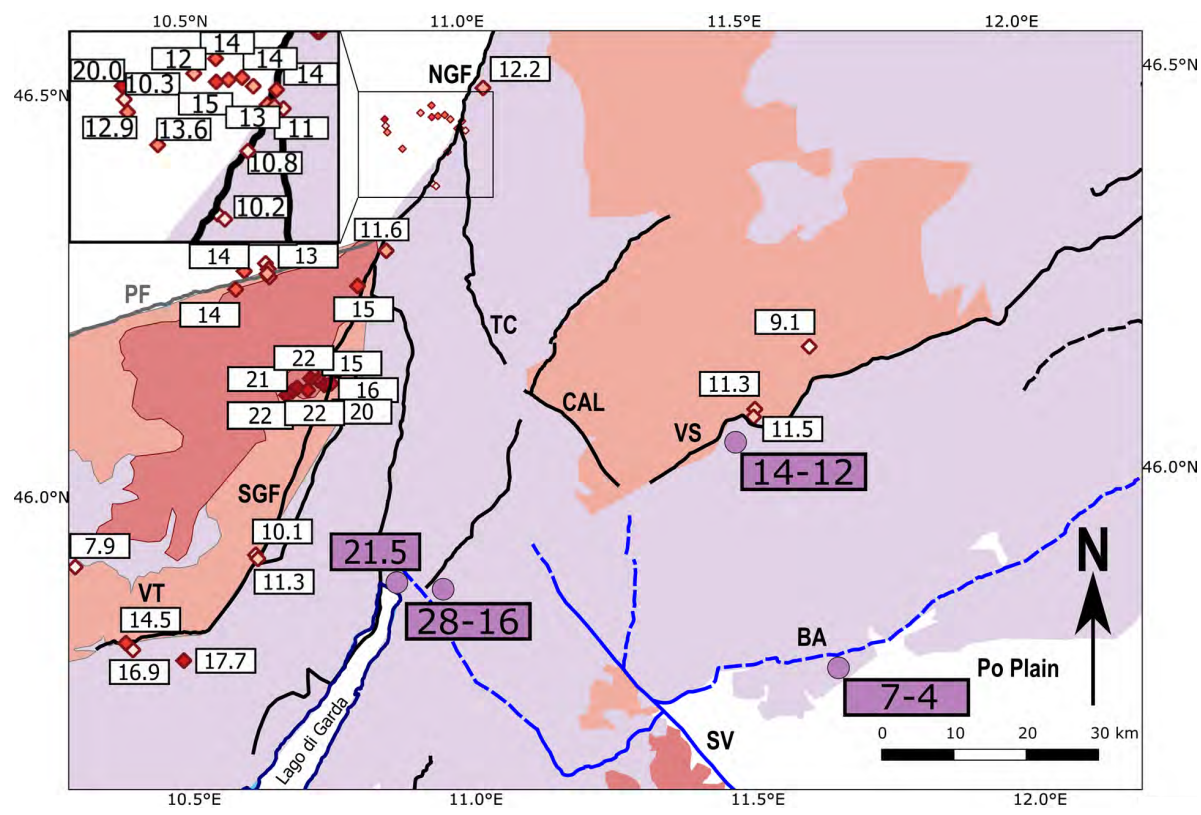

Figure 5. Compilation of stratigraphic and AFT age data in the eastern Southern Alps from Luciani and Silvestrini (1996), Martin et al. (1998), Castellarin and Cantelli (2000), Viola et al. (2001), Stipp et al. (2004), Pomella et al. (2011, 2012), and Heberer et al. (2016). Purple boxes mark biostratigraphic ages of deformed sediments (Castellarin et al., 1992). The inset map outlines the Adamello-Giudicarie area at the junction of the NGF and TC faults, with the locations of many tightly spaced age data. See Fig. 1 for fault abbreviations.

mano et al., 2019; Anderlini et al., 2020; Jozi Najafabadi et al., 2021) along these fault systems and morphological evidence of fault surface rupture (Moratto et al., 2019; Romano et al., 2019) indicate that this younger phase of shortening is still active.

The Adamello granitoids, the Variscan basement, and overlying Permian volcanics are better suited for geochronological studies, as reflected in the clustering of age data within these rock units (Fig. 5). Early to Late Miocene thermochronological ages along the NGF (Viola et al., 2001; Pomella et al., 2011, 2012) and within the Val Trompia sector of the Giudicarie Belt (Heberer et al., 2016; VT in Fig. 5) fall within the same age interval as the stratigraphic constraints above, indicating the coeval evolution of the NGF and Giudicarie Belt.

In addition, pre-Oligocene ages of shortening have been reported in the eastern Dolomites (Doglioni and Bosellini, 1987) based on similarities with Dinaric thrust directions and Oligocene deposits unconformably overlying Mesozoic strata (Doglioni and Bosellini, 1987; Keim and Stingl, 2000). However, these faults only occur east of our study area.

West of the SGF, a pre-Adamello phase of shortening is recognized along the Val Trompia sector of the Giudicarie Belt (Brack, 1981; Doglioni and Bosellini, 1987; Picotti et al., 1995; Castellarin et al., 2006b). Relative age constraints are provided here by the observation that the Gallinera Fault is cross-cut by the western side of the Adamello batholith (Brack, 1981; Picotti et al., 1995; Castellarin et al., 2006b), which indicates a pre-Adamello (possibly Cretaceous) age of deformation. However, within our study area east of Adamello, no such indications for pre-Adamello deformation can be found. This suggests the presence of a Cretaceous lateral ramp between the western and the eastern Southern Alps (Doglioni and Bosellini, 1987; Castellarin et al., 2006b).

\section{Shortening estimates and depth of detachment in the eastern Southern Alps}

\subsection{Assumptions for structural analysis and cross section balancing}

All kinematic models of the Giudicarie Belt agree that deformation involved Neogene transpression with strain partitioning between strike-slip and thrust faults (Picotti et al., 1995; Prosser, 1998, 2000). To obtain reliable estimates of shortening across the belt, it is necessary to account for rock volumes moving into and out of $2 \mathrm{D}$ section traces. Seven cross sections were constructed parallel to the NNWSSE Neogene direction of the principal shortening direction obtained from fault-slip analysis above (Fig. 3e). These cross sections straddle the Schio-Vicenza, Trento-Cles, and Ballino-Garda faults (Fig. 6), which, as we have shown above, coincide with the main boundaries of paleogeographic zones (Fig. 2). In addition, seven perpendicular (orogenparallel) cross sections were constructed to assess stratigraphic variations across these faults (Fig. 6). Stratigraphic and tectonic contacts were projected into the sections using structural contours constructed from published geolog- 
ical maps (Bartolomei et al., 1969; Bosellini et al., 1969; Castellarin et al., 1968, 2005; Braga et al., 1971; Dal Piaz et al., 2007; Avanzini et al., 2010). In addition, publicly available borehole data for the southern part of the studied area beneath the Po Plain (Paese, Scaldaferro, Travettore and Villaverla wells; VIDEPI-database: https://www.videpi. com/videpi/videpi.asp, last access: 11 May 2021) constrain the thickness of the sedimentary cover. Thickness variations within the paleogeographic zones of Fig. 2 are neglected and only variations across these major paleogeographic boundaries are incorporated in the cross sections. Thicknesses within the profiles were extrapolated to depth and above the current erosional level using the kink-band and dip-domain methods (Boyer, 1986).

Line-length balancing was performed with the Move software package (provided by Petex) using the flexural slip algorithm for unfolding the horizons. We assumed a flat top Cretaceous horizon and used this as a marker to estimate the fault displacements. This is admittedly a simplification given the lateral facies and thickness variations in Cretaceous strata (Doglioni and Bosellini, 1987). Modelled fault geometries at depth were tested using a trial and error, forward modelling approach until a best fit with the presentday surface geology was found. We assumed that all the observed folds along the profiles are fault-related and employed a fault-bend-fold algorithm (Suppe, 1983) in Move. This algorithm treats faults as brittle, discrete discontinuities, even at depths below $\sim 10 \mathrm{~km}$ where ductile behaviour is expected in natural systems. The fault-bend-fold algorithm maintains line length and area in forward modelling, in contrast to its alternative, fault-parallel flow, which only maintains line length when a correct angle of angular shear is specified. We avoided fault-parallel flow modelling because this angle is not well constrained in the studied area. It is inferred that the Northern Giudicarie Fault (NGF) forms the backstop of the south-vergent Neogene deformation of the eastern Southern Alps and that all interpreted detachments are connected at depth with the NGF. This is in line with the absence of any significant Neogene deformation in the Austroalpine basement to the NW of the NGF. It is clear that sinistral strikeslip motion of up to $75 \mathrm{~km}$ along the NGF itself was coeval with thrusting in the Giudicarie Belt (e.g. Pomella et al., 2011), but transpressional movement cannot be incorporated in the fault-bend-folding algorithm of Move. Thus, in forward modelling of all cross sections, the NGF is progressively offset as a passive marker along the fault detachments (Figs. 7, 8 and 9).

The 3D Move database, including all 14 cross sections, as well as descriptions of selected cross sections 1,5 , and 6 and details on the forward modelling approach, are available in Verwater et al. (2021; see data availability section below). Regardless of the balancing methods employed here, all estimates of shortening must be regarded as minima. There are several basic reasons for this: (1) the cutoff lines of strata in the hanging wall of many thrusts have been eroded, such that markers for determining the full amount of displacement are lacking. This is particularly true of the highest detachments in a thrust system, where erosion is greatest. (2) Many detachments in the deeper levels of thrust systems are "blind", i.e. the displacement at their tips tends to zero at depths where constraints on the geometry of their propagation structures (e.g. folds) are poorly constrained or even unconstrained. This is particularly the case where boreholes or seismic information are unavailable, as in the foreland of some of the thrust systems reported below. (3) In extreme cases, thrust systems can "cannibalize" their own deepest detachments, removing them to depths beyond detection with available seismic information. This type of tectonic erosion, especially in basement units with low impedance contrasts, will always lead to an underestimation of shortening. (4) Out-of-section motion, for example the sinistral strikeslip component in the Giudicarie Belt, necessarily renders 2D areal and line balancing inadequate for determining the true amount of shortening. (5) Alternative structural interpretations involving duplexes and/or triangle zones at depth increasing the amount of shortening (see discussion in Sect. 5.2 and Verwater et al., 2021). We have attempted to compensate for this innate bias by balancing shortening in the aforementioned network of closely spaced cross sections, and in fact we use the differences in minimum shortening estimates to judge the degree of transpression within the Giudicarie Belt (Sect. 6 below). Despite these limitations, the minimum shortening estimates allow us to place a lower limit on the amount of shortening parallel to the bulk shortening direction within the Giudicarie Belt.

\subsection{Results of shortening estimates from cross section balancing}

Amounts of shortening in orogen-normal profiles vary laterally along the Giudicarie Belt (Fig. 6). To the southwest (profiles 1 and 2), balancing yield $18-22 \mathrm{~km}$ of shortening. Similarly, to the northeast (profiles 6 and 7), shortening estimates range from 17 to $25 \mathrm{~km}$. However, shortening is only 8 to $12 \mathrm{~km}$ in the central part of the Giudicarie Belt (profiles 3, $4,5)$. The largest variation in shortening occurs between profiles $5(11 \mathrm{~km})$ and $6(25 \mathrm{~km})$ across the TC-SV fault system (Figs. 6, 8 and 9). We infer a dominantly thick-skinned style of deformation, with detachments reaching down to $\sim 15 \mathrm{~km}$ depth based on exposure of basement in the hanging wall of steep thrusts, recent seismicity clustering at depths of 10 to 20 km (Viganò et al., 2015; Jozi Najafabadi et al., 2021) and forward modelling in Move (Figs. 6, 7, 8 and 9; Verwater et al., 2021).

These minimum shortening estimates are fairly well constrained, as the fault displacement observed at the surface provides the most important constraint for the amount of shortening, and uncertainties of fault structures at depth have errors of 2-3 km (see discussion in Verwater et al., 2021). Although the Giudicarie Belt exposes several long décolle- 


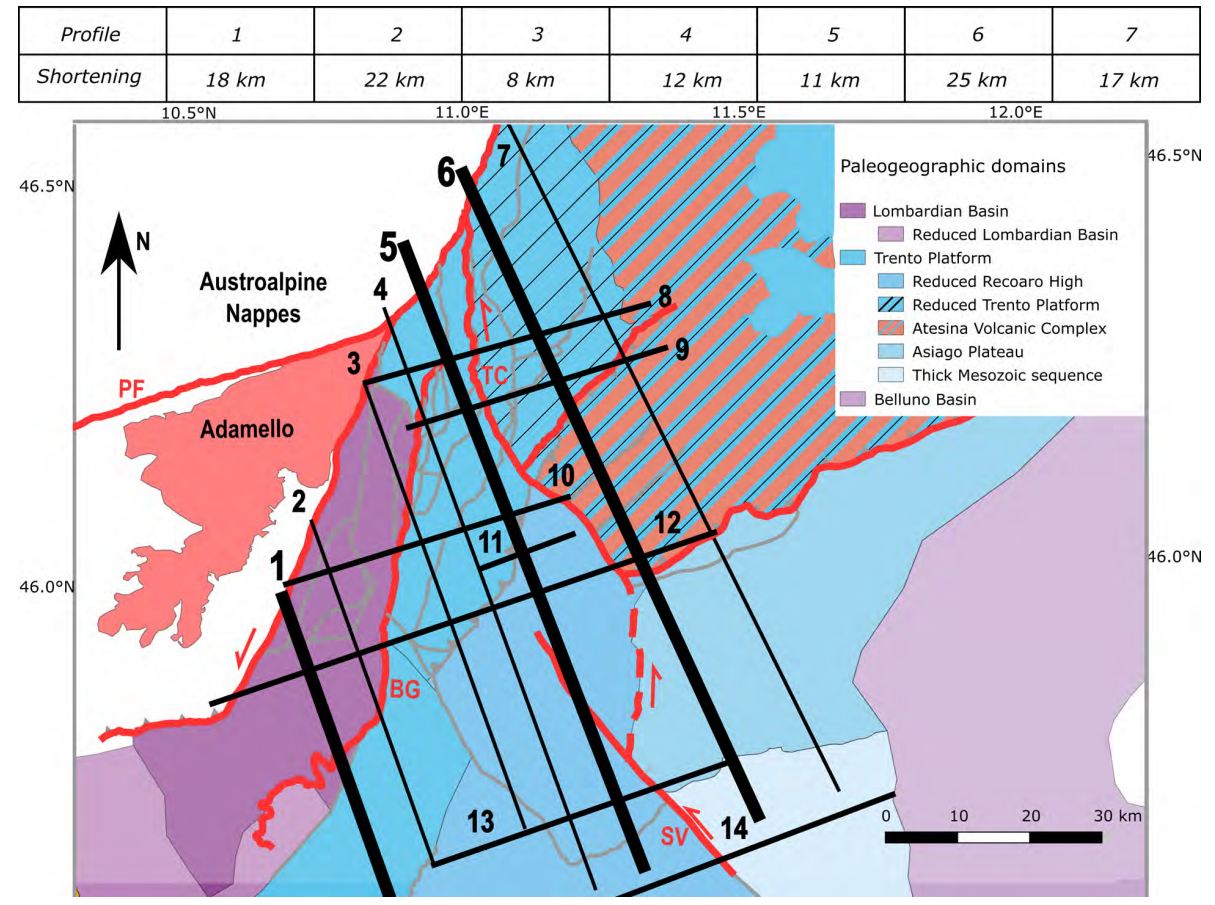

Figure 6. Traces of cross sections constructed and balanced in this study. Details of profile reconstructions for profiles 1,5 , and 6 (thick black lines) are shown on Figs. 7, 8, and 9, respectively. Profiles not shown in Figs. 7, 8, 9, and 10 are available in Verwater et al. (2021). Abbreviations are as follows: BG stands for Ballino-Garda Fault, PF stands for Periadriatic Fault, SV stands for Schio-Vicenza Fault, and TC stands for Trento-Cles Fault.

ments within the sedimentary cover (e.g. Tremosine-Tignale, Paganella and Tosa Faults; Figs. 7 and 8), field observations show that, with the exception of the Mezzocorona antiformal stack along profile 6 (Fig. 9a), there are no large-scale duplexes exposed. This suggests that kinematic models with several putative duplexes at depth are inconsistent with field observations. However, the geometries in the footwall of the Paganella (profile 5; Fig. 8) and Valsugana Faults (profile 6; Fig. 9) allow for alternative interpretations in which possible duplexes at depth are linked with shortening at the surface. These duplexes would increase shortening along profiles 5 and 6 by $\sim 2$ to $3 \mathrm{~km}$ (see alternative interpretations of profiles 5 and 6 in the data repository of Verwater et al., 2021). The $3 \mathrm{~km}$ uncertainty in shortening along profile 5 is $27 \%$ of the total minimum amount of shortening observed along this profile and can also be taken as a percentage of uncertainty in the shortening estimates of the other profiles (Fig. 6). The presence of eroded hanging wall cutoffs along our profiles (Figs. 7, 8 and 9) could yield additional errors in our shortening estimates, further increasing the $27 \%$ uncertainty. In addition, the clustering of seismic events along modelled fault structures in the basement propagating southward in profiles 1, 5, and 6 (Figs. 7, 8, and 9; Jozi Najafabadi et al., 2021) is consistent with thick-skinned tectonics featuring ramps that root in the basement units.

\subsection{Forward modelling of fault detachments at depth}

Sub-surface faults in profiles 1-7 (Figs. 7, 8, 9 and 10) were determined from forward modelling of an initial undeformed state involving layer-cake stratigraphy (Figs. 7b, $8 \mathrm{~b}$ and $9 \mathrm{~b}$ ). This assumption is necessary for balancing, though in light of the aforementioned Mesozoic rifting in this area (Sect. 3), layer-cake stratigraphy is only an approximation of the preNeogene structure. All the NNW-SSE profiles were tested with one, two, or three basement nappe slices involved in thrusting. Within the Lombardian Basin and Trento Platform along profiles 1 and 5, the surface geology was best reproduced with two basement thrust sheets (Figs. 7c and 8c). We interpret the Mesozoic Ballino-Garda Fault (Fig. 2) as ramping down to pre-Permian basement and connecting at depth with a basement detachment (Fig. 7c). However, for the Reduced Trento Platform and Atesina Volcanic Complex along profile 6 (Fig. 9c), the surface geology was best reproduced with three basement thrust sheets. The $10-12 \mathrm{~km}$ depth of the lower detachment in profile 1 suggests a possible connection with the lower detachment in profile 5 and the middle detachments of profile 6, both situated at 10-12 km depth (Figs. 7, 8 and 9). A possible correlation between the bottom detachments of profiles 5 and 6 is suggested by similar detachment geometries and depths down to 15 to $20 \mathrm{~km}$. Lateral jumps of a few kilometres in detachment level (Fig. 10) are interpreted to occur along major steep Permo-Mesozoic faults. 


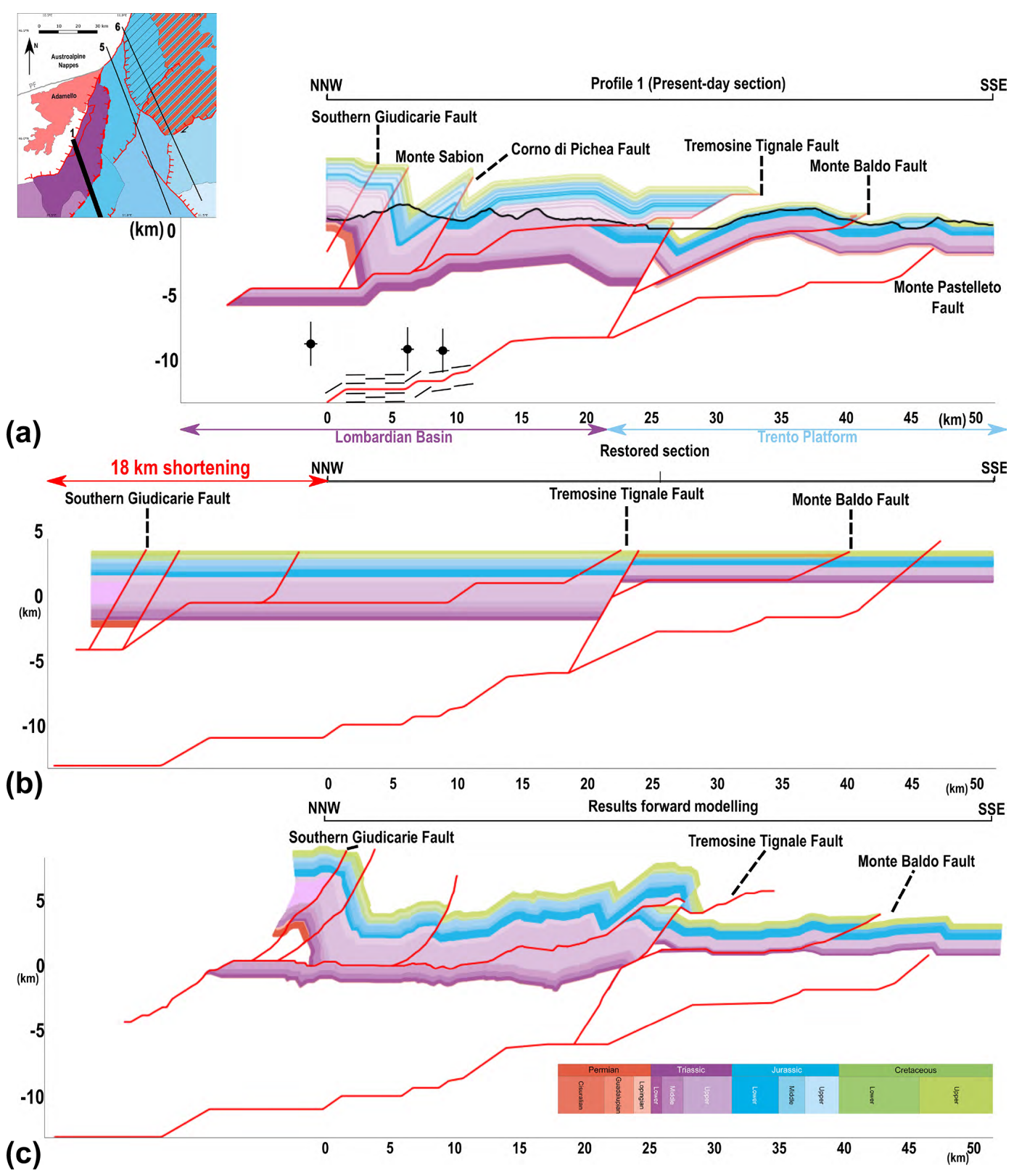

Figure 7. (a) Profile 1 across the Lombardian Basin and Trento Platform. (b) Profile 1 retro-deformed to a layer-cake stratigraphy. (c) Results of forward modelling. Colours in the legend are modified following the International Chronostratigraphic Chart, with the pre-Permian basement beneath in white. Black dots indicate earthquake hypocentres during 2017-2018 (SWATH-D Network; Jozi Najafabadi et al., 2021; vertical bars indicate the average error range on hypocentre depths), projected from a swath covering $6 \mathrm{~km}$ on either side of the profile. Dashed black lines below $\sim 10 \mathrm{~km}$ indicate ductile deformation.

These fault jumps could be an artefact produced by the uncertainty of the fault geometries at depth within the forward modelling in Move. Such a deep basement level is required in forward models to reproduce the structures associated with the Bassano Fault west of the Schio-Vicenza Fault.

Recently, the SWATH-D seismic network (Heit et al., 2021) provided accurate hypocentres in the study area (average vertical and horizontal resolutions of $\sim 1.7 \mathrm{~km}$ and of $\sim 0.5 \mathrm{~km}$, respectively; Jozi Najafabadi et al., 2021), basi- cally confirming existing seismicity patterns (e.g. Viganò et al., 2015). The seismicity indicates that the most frontal fault systems within the eastern Southern Alps are active (Figs. 7a, $8 \mathrm{a}$ and $9 \mathrm{a})$. Plotted onto the cross sections, the hypocentres provided an additional independent constraint on the depth of basement fault nappes and indicate a possible blind thrust system propagating southward in profiles 1-7 (Figs. 7a, 8a and 9a), (Jozi Najafabadi et al., 2021). Note that seismicity does not necessarily delineate all active faults, as deforma- 


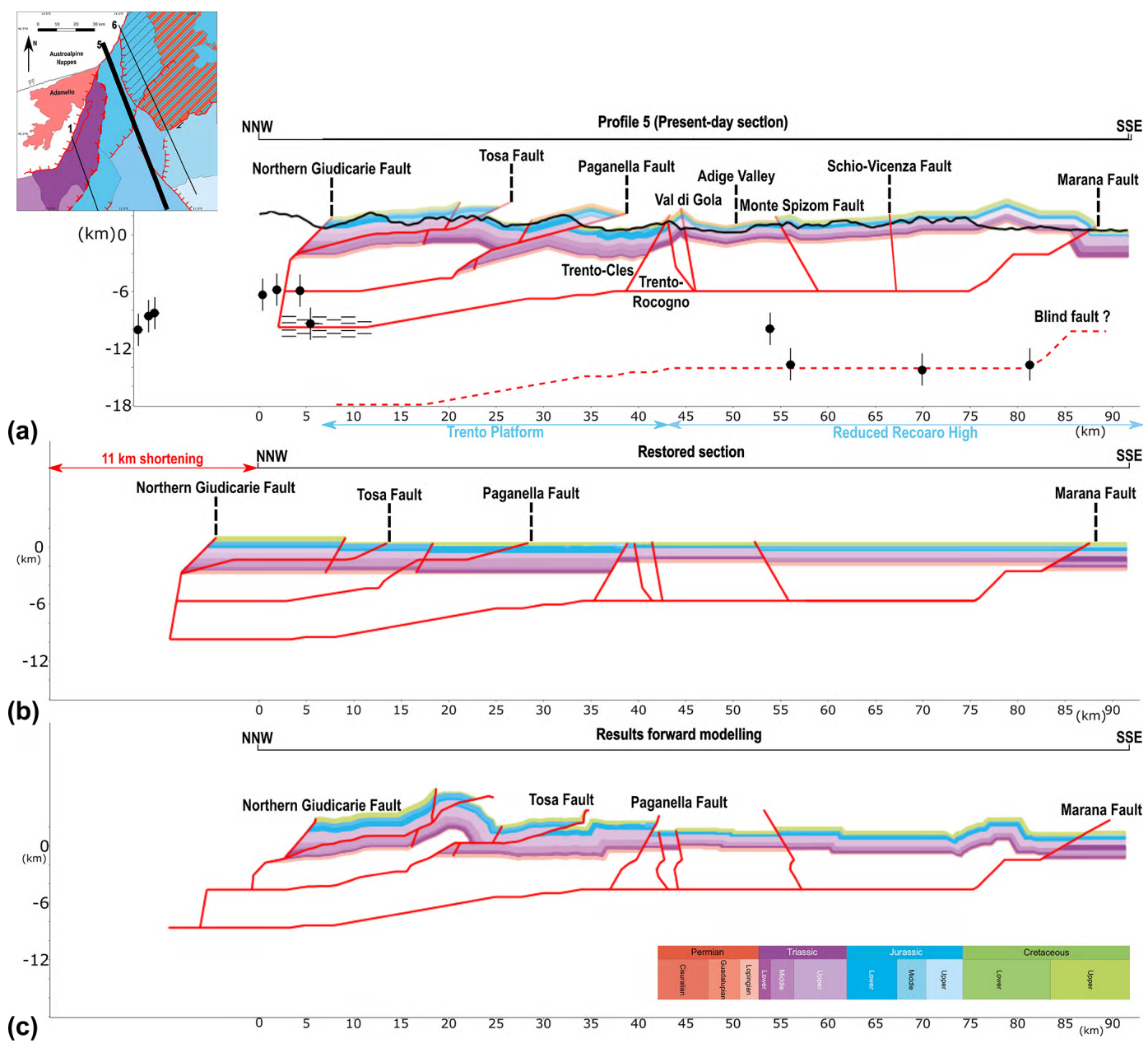

Figure 8. (a) Profile 5 across the Trento Platform and its structural Recoaro High. (b) Profile 5 retro-deformed to a layer-cake stratigraphy. (c) Results of forward modelling. Colours in the legend are modified following the International Chronostratigraphic Chart, with the pre-Permian basement beneath in white. Black dots indicate hypocentres of seismic events during 2017-2018 (SWATH-D Network; Jozi Najafabadi et al., 2021; vertical bars indicate the average error range on hypocentre depths), projected from a swath covering $6 \mathrm{~km}$ on either side of the profile. Dashed black lines below $\sim 10 \mathrm{~km}$ indicate ductile deformation.

tion may occur aseismically (Sect. 6.2) or occur along different structures than the main basement thrust. We note that some hypocentres are plotting below the modelled fault detachments (Figs. 7, 8 and 9), possibly indicating the development of an even deeper southward-propagating thrust sheet (Jozi Najafabadi et al., 2021). This is in agreement with focal mechanisms of recent earthquakes, indicating a thrusting regime (Petersen et al., 2021). Along profile 6 (Fig. 9), this deeper deformation may be linked with the ThieneBassano Fault (Galadini et al., 2005; Burrato et al., 2008), whose surface expression is the Montecchio-Precalcino Hill (Viganò et al., 2018), situated in isolation on the Po Plain south of the Bassano Fault (Fig. 1). At this location, the Villaverla well (VIDEPI-database: https://www.videpi.com/ videpi/videpi.asp, last access: 11 May 2021) crosses a gentle anticline fold, indicating a development in the hanging wall of a blind thrust (Viganò et al., 2018). This may introduce an additional amount of shortening to profile 6 (Fig. 9), although we do not expect this be more than $\sim 1-2 \mathrm{~km}$. In addition, no offset sediments can be observed at the MontecchioPrecalcino and therefore it is indicated as a dashed line on Fig. 9. Along profile 5 no deep blind faults have been reported in the literature; however, deep seismic events (Fig. 8) suggest the presence of a blind thrust sheet.

\section{Discussion}

\subsection{Kinematic divisions of the Giudicarie Belt}

The lateral variation in shortening described above follows Permian-Mesozoic paleogeographic zones (Fig. 6), whose boundaries were reactivated as strike-slip faults during the Neogene. This is consistent with field observations along the Ballino-Garda, Schio-Vicenza, and Trento-Cles faults and 


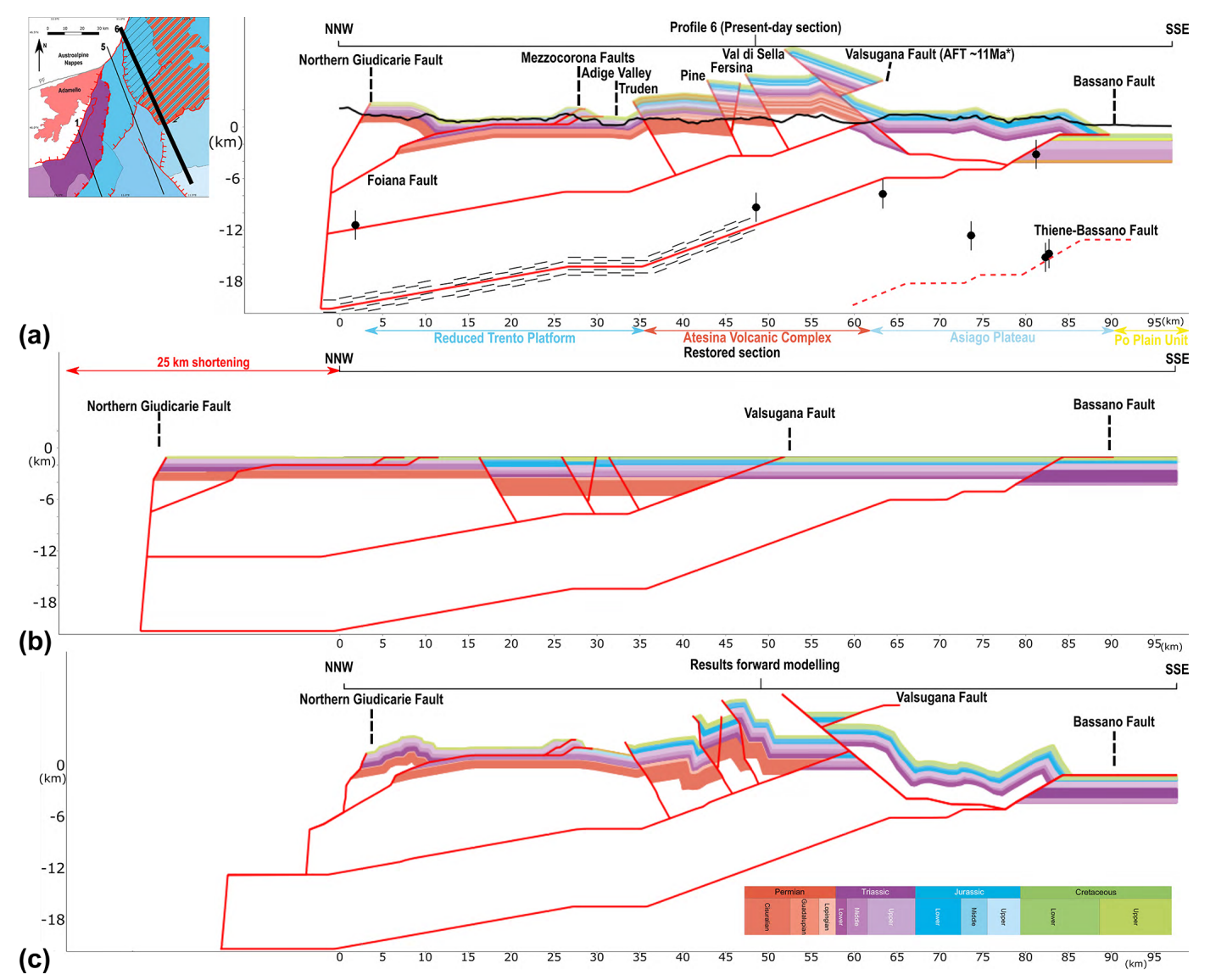

Figure 9. (a) Profile 6 across the Reduced Trento Platform, Atesina Volcanic Complex, and the Asiago Plateau (AFT age for Valsugana Fault from Heberer et al., 2016). (b) Profile 6 retro-deformed to a layer-cake stratigraphy. (c) Results of forward modelling. Colours in the legend are modified following the International Chronostratigraphic Chart, with the pre-Permian basement beneath in white. Black dots indicate hypocentres of seismic events during 2017-2018 (SWATH-D Network; Jozi Najafabadi et al., 2021; vertical bars indicate the average error range on hypocentre depths), projected from a swath extending to $6 \mathrm{~km}$ on either side of the profile. Dashed black lines below $\sim 10 \mathrm{~km}$ indicate ductile deformation.

fault-slip analysis indicating strike-slip motion along these faults (Fig. 4). We interpret the TC-SV fault system to act as a major sinistral transfer zone (Fig. 11), accommodating the largest variation of shortening along the Giudicarie Belt (between profiles $5(11 \mathrm{~km})$ and $6(25 \mathrm{~km})$; Fig. 6$)$ and therefore subdividing the area into two kinematic domains (1) and (2), west and east of the TC-SV fault system, respectively (Fig. 11).

Based on age constraints (Sect. 4), we further subdivide the shortening phases along each cross section into southern (actively deforming) and northern (inactive) segments. We estimate the amount of strike-slip motion along the TCSV fault system by comparing shortening on either side of the fault (Fig. 11), which results in minimum estimates of $4 \mathrm{~km}$ along the SV and $9 \mathrm{~km}$ along the TC. Strike-slip motion along the Ballino-Garda Fault is estimated to be no more than $6 \mathrm{~km}$ (Picotti et al., 1995). As profile 5 straddles the SV and profiles 3 and 4 intersect the Ballino-Garda Fault, the amount of shortening along these profiles may be underestimated by a few kilometres due to movement of rock volume out of the 2D section trace.

The difference in shortening within the three sectors is attributable to changes in stratigraphy across these faults that are inherited from Permo-Mesozoic time. For example, in the western sector within the Lombardian Basin, most shortening is taken up by the thin-skinned Tremosine-Tignale Fault, which has a long detachment at the base of the Calcare Di $\mathrm{Zu}$ and consequently stacks the Dolomia Principale (Fig. 7a). The Ballino-Garda Fault is its lateral ramp (Picotti et al., 1995) and therefore does not continue to the Trento Platform. The sedimentary cover is much thicker in the Lombardian Basin than in the Trento Platform (Fig. 2) and comprises a thick Jurassic sequence of slope and deep-water deposits that favour the development of extended décollements. In the Trento Platform, similar stacking of the Dolomia Principale can be observed along the Tosa, Mezzocorona, and Paganella Faults (Figs. 8 and 9). However, their fault displacements are 

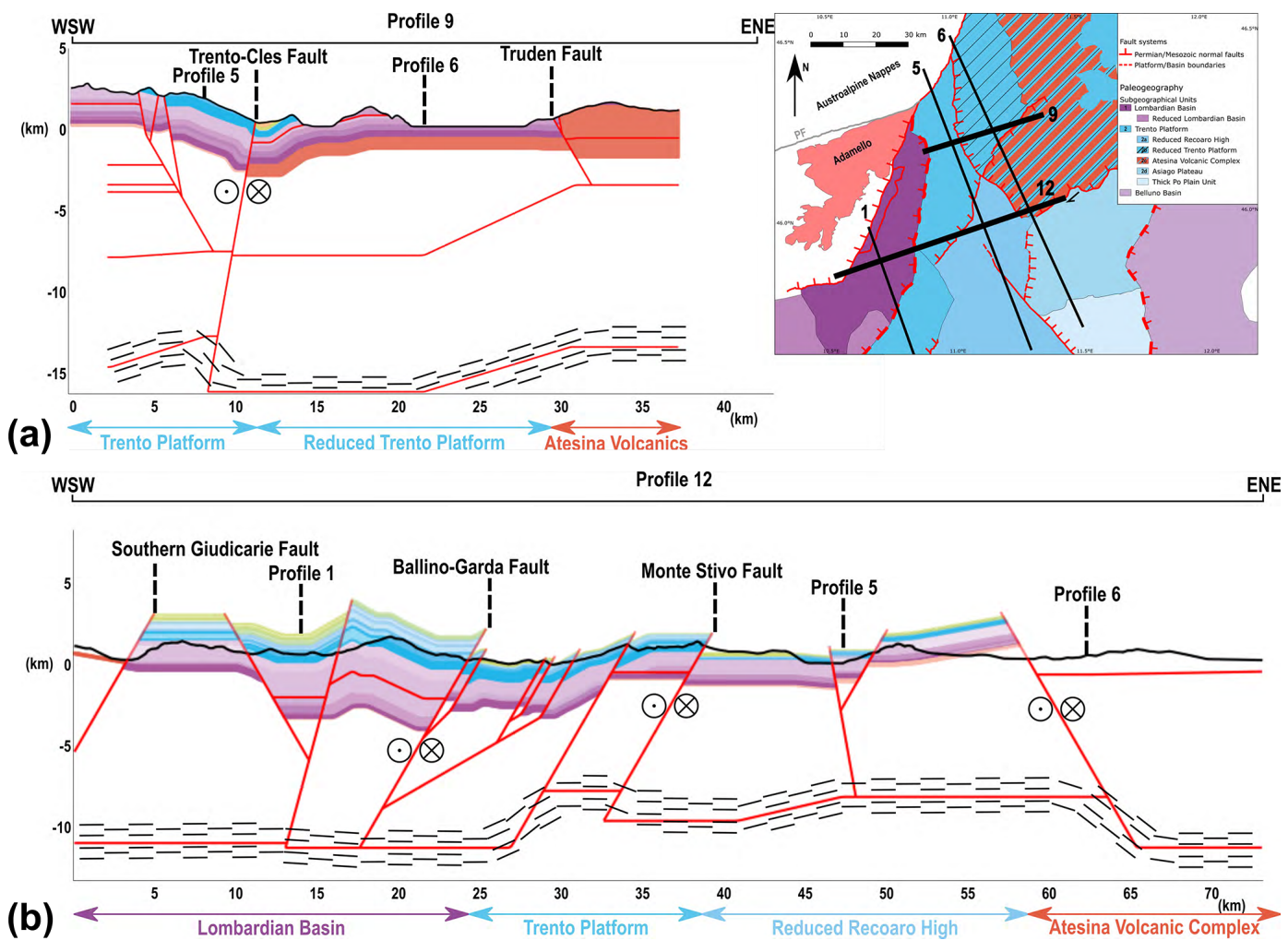

Figure 10. (a) Profile 9 across the Trento-Cles Fault separating the Trento Platform and Reduced Platform. (b) Profile 12 across the BallinoGarda Fault between the Lombardian Basin and Trento Platform. Dashed lines at and below $\sim 10 \mathrm{~km}$ indicate ductile deformation.

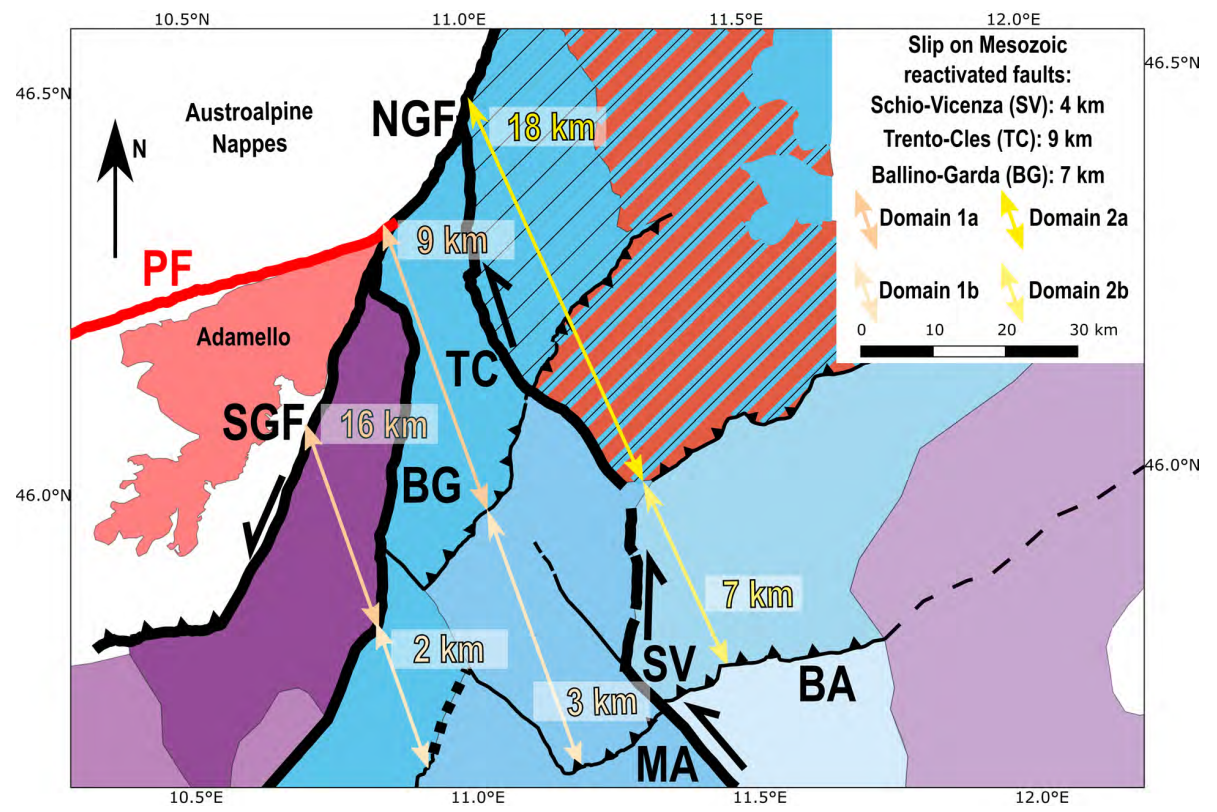

Figure 11. Lateral variation of shortening coinciding with paleogeographic zones (Fig. 2), bounded by Mesozoic faults (BG, SV, TC) that were reactivated as Neogene strike-slip faults. The TC-SV fault system accommodated the largest variation of shortening and subdivides the area into two kinematic domains west and east thereof, domain (1) and (2), respectively. Each profile is furthermore subdivided into a northern and southern segment based on the age of deformation, with the northern domains indicating older deformation of the Giudicarie or Valsugana phase, and southern domains showing a younger, active phase of shortening along the Southern Alpine orogenic front (labelled as the Marana (MA) and Bassano Faults (BA); see Fig. 12). See Fig. 1 for fault abbreviations. 
much smaller, possibly due to the presence of different décollement layers within the sedimentary cover.

Another example is in the eastern sector (northeast of TCSV fault system), where most shortening is taken up by the Valsugana Fault and the inversion of a Permian graben containing the Atesina Volcanic Complex. The Calisio Fault represents the lateral ramp of the Valsugana Fault, which is connected with the Trento-Cles Fault (Fig. 1; Selli et al., 1996), indicating the Valsugana Fault cannot be traced to the Trento Platform. Although the Valsugana Fault exhumes pre-Permian basement in its hanging wall, the sedimentary cover of the Atesina Volcanic Complex is much thicker than that of the Trento Platform and contains competent volcanic and pyroclastic deposits of the Lower Permian Formazione di Ora and Formazione di Gargazzone, which are less abundant within the Trento Platform. We propose that the thick sedimentary cover of the Atesina Volcanic Complex favoured a different tectonic style with a contrasting amount of shortening due to the reactivation of former Permian normal faults as steep Neogene thrusts.

We argue that these local variations in shortening in the eastern Southern Alps are related to inherited paleogeographic features from Permian to Jurassic times with the majority of the deformation focused within the Lombardian Basin and the Atesina Volcanic Complex, which have a thicker sedimentary cover than the Trento Platform, which is composed of mainly competent carbonate platforms. Moreover, internal fragmentation of the Adriatic indenter along the NGF and TC-SV fault system played a major role in strain partitioning (discussed in Sect. 6.2)

\subsection{Lateral variations in Neogene shortening across the eastern Southern Alps}

The presented model of dominantly thick-skinned tectonics with three basement thrust sheets is in agreement with the cross section across the Dolomites of Schönborn (1999). However, Schönborn (1999) estimated twice the shortening in his profile across the Dolomites ( $>50 \mathrm{~km}$; orange line on Fig. 12). Although his cross section transects the Belluno Thrust, which is not considered in our study, the 4-5 km of displacement along this thrust (Schönborn, 1999) is insufficient to explain the difference in shortening (ca. $25 \mathrm{~km}$ ). In fact, shortening estimated by Schönborn (1999) along the Valsugana-Belluno system $(22 \mathrm{~km})$ is similar to our estimate of $18 \mathrm{~km}$ along this same system (Fig. 9). The difference between Schönborn (1999) and our study is mainly due to different interpretations of the Bassano Fault, which Schönborn associated with $33 \mathrm{~km}$ of shortening, while we only propose $7 \mathrm{~km}$. The $33 \mathrm{~km}$ estimate of Schönborn (1999) is based on hinterland-dipping panels above footwall ramps, which must be matched with hanging wall geometries. Other profiles transecting the Bassano Fault published by Selli (1998) (close to the TC-SV fault system; parallel to our profile 6) and Castellarin and Cantelli (2000) (parallel to the section of
Schönborn, 1999; orange section in Fig. 12) indicate 33 and $35 \mathrm{~km}$ of Neogene shortening, respectively, of which 14 and $19 \mathrm{~km}$ were accommodated by the Bassano Fault. Along profile 6 (Fig. 9), surface measurements of layer dips indicate that several hinterland-dipping strata of Schönborn (1999) are not observed at the surface in the hanging wall of the Bassano Fault. Therefore, we prefer the $7 \mathrm{~km}$ shortening estimate in our study area (Fig. 9) and the $19 \mathrm{~km}$ toward the east from Castellarin and Cantelli (2000) to the $33 \mathrm{~km}$ of Schönborn (1999).

More to the east, Nussbaum (2000) presented cross sections with several basement thrust sheets and an estimated minimum of $50 \mathrm{~km}$ shortening (blue line on Fig. 12). To the west of the Giudicarie Belt, Picotti et al. (1995) obtained shortening estimates of 30 to $40 \mathrm{~km}$ (purple line on Fig. 12). The main difference between cross sections $\mathrm{h}$, $\mathrm{g}$, and $\mathrm{f}$ of $\mathrm{Pi}$ cotti et al. (1995) and cross sections 1 to 7 of this study is the major thin-skinned component of shortening beneath the Po Plain west of Lake Garda (Picotti et al., 1995; and references therein); this shortening decreases towards its lateral ramps up to the Adige Valley. Such buried thin-skinned shortening is not present further to the east, as shown by a seismic survey across the Po Plain directly east of the Schio-Vicenza Fault (Pola et al., 2014).

In addition, the TC-SV fault system seems to be the lateral boundary for most thrust systems, as thrusts merge with it and cannot be traced across. It also coincides with contrasting (though partly overlapping) ages of shortening (Fig. 11), which forms the basis for a distinction between kinematic domains 1 and 2 (Fig. 12). Kinematic domain 1 contains the Val Trompia sector of the Giudicarie Belt with $\sim 18 \mathrm{~km}$ of Late Oligocene to Early Miocene shortening along thrusts that merge with the NGF and SGF (Picotti et al., 1995; Fig. 12). The same thrusts then accommodated at least $\sim 12-22 \mathrm{~km}$ of Middle Miocene to recent shortening. In kinematic domain 2, a minimum of $25 \mathrm{~km}$ of post-Middle Miocene shortening (Figs. 6, 9, 11 and 12) was accommodated directly east of the TC-SV fault system, broadly coeval with shortening in kinematic domain 1 . Given the proximity of profile 6 to the TC-SV fault system, a major strike-slip corridor, significant out-of-plane motion along these profiles may have occurred. Therefore, we have included the estimated $35 \mathrm{~km}$ of Neogene shortening of Castellarin and Cantelli (2000) in the Neogene displacement vector triangle of domain 2 (Fig. 12).

We note that the shortening directions in the eastern Southern Alps shifted from NNE-SSW during the Late Oligocene to Early Miocene towards NNW-SSE during the Middle Miocene. The Late Oligocene shortening direction has been determined with mesostructural analysis and tectonic reconstructions (Castellarin et al., 1992; Picotti et al., 1995) based on field data (Schönborn, 1992; Picotti et al., 1997) and subsurface data (e.g. Fantoni and Franciosi, 2010). This shift in shortening directions is an important constraint on drawing displacement vector triangles (Fig. 12), as the hypotenuse of these should be parallel to the motion direction. Conse- 


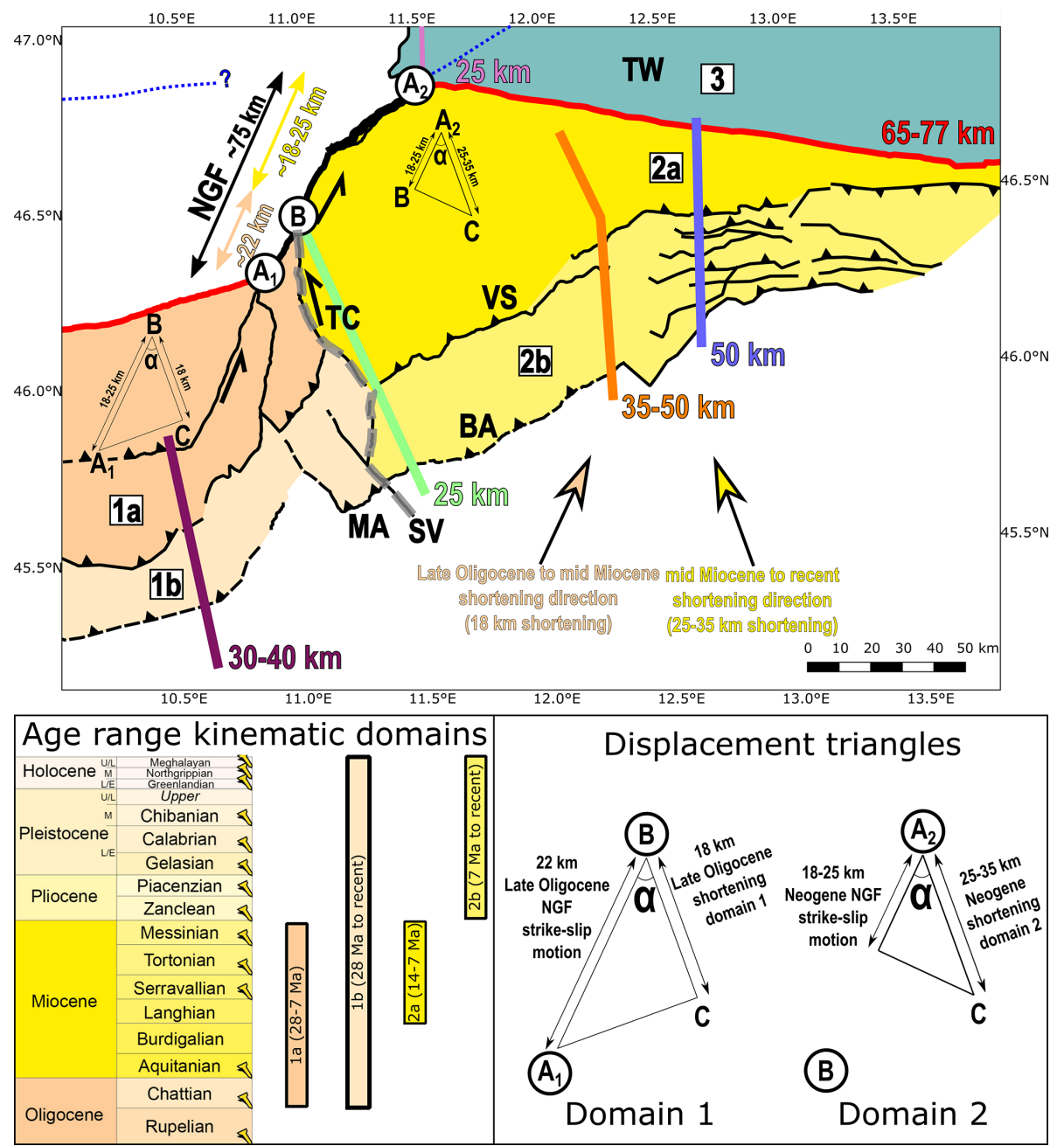

Figure 12. Kinematic map of the eastern Southern Alps, divided into two domains east and west of the TC-SV fault system (dashed grey). These made contrasting and partly overlapping kinematic contributions to sinistral strike-slip offset along the NGF. The subdivision into domains $1 \mathrm{a}, 1 \mathrm{~b}, 2 \mathrm{a}$ and $2 \mathrm{~b}$ is based on the age of deformation (see the legend and Sect. 4). Seismicity in domains $1 \mathrm{~b}$ and $2 \mathrm{~b}$ indicates that shortening is still ongoing. Profile traces from this study (green), Picotti et al. (1995, purple), Schönborn (1999, orange, parallel to the cross sections of Castellarin and Cantelli, 2000), Nussbaum (2000, blue), Favaro et al. (2017) (pink), and the inferred surface trace of a putative Adriatic crustal wedge (Gebrande et al., 2002, dashed blue) are indicated. Triangle $\mathrm{A}_{1} \mathrm{BC}$ depicts the geometrical relationship between Late Oligocene to Early Miocene shortening in kinematic domain 1 of the Giudicarie Belt (vector $\boldsymbol{B} \boldsymbol{C}$ ) and motion along the NGF (vector $\boldsymbol{A}_{2} \boldsymbol{B}$ ), which is estimated to be $\sim 18-25 \mathrm{~km}$. This was obtained by projecting $18 \mathrm{~km}$ of shortening along the Val Trompia sector of the Giudicarie Belt (Picotti et al., 1995, purple). Triangle $\mathrm{A}_{2} \mathrm{BC}$ depicts the geometrical relationship between Middle Miocene shortening in kinematic domain 2 of the Giudicarie Belt (vector $\mathrm{A}_{2} \mathrm{C}$ ) and motion along the NGF (vector $\mathrm{AB}$ ), which is estimated to be at least $\sim 35-50 \mathrm{~km}$. This was obtained by projecting $25-35 \mathrm{~km}$ (green) of minimum shortening across the Giudicarie Belt east of the TC-SV fault system. Fault abbreviations are as follows: BA stands for Bassano, MA stands for Marana, NGF stands for Northern Giudicarie Fault, SV stands for Schio-Vicenza, and VS stands for Valsugana.

quently, the hypotenuse of the Late Oligocene displacement triangle is oriented NNE-SSW (Fig. 12; parallel to NGF and oblique to the profile from Picotti et al., 1995), whereas the hypotenuse of the Middle Miocene displacement triangle is oriented NNW-SSE (Fig. 12; parallel to profiles 1 to 7). Using this triangular approach, we estimate $40-47 \mathrm{~km}$ of Late Oligocene to Middle Miocene displacement along the NGF, a calculation we discuss step by step in Sect. 6.4.
Based on stratigraphic and radiometric age criteria (Sect. 4), we further divide domains 1 and 2 into sub-domains $\mathrm{a}$ and $\mathrm{b}$ (Fig. 12), with ongoing shortening in domain $\mathrm{b}$ indicated by seismicity. Low instrumental seismicity and high strain rates in the central part of domain $2 b$ (Fig. 13; Serpelloni, 2016) might indicate a seismic gap (Anselmi et al., 2011). Note that strain rates are also relatively high in the Friuli area, where there is a prominent cluster of seismicity 
(Fig. 13; see, e.g. Bressan et al., 2016). This could be due to its junction with the Dinaric system and/or an increase of shortening towards the east (Nussbaum, 2000) due to anticlockwise rotation of Adria with respect to Europe (e.g. Ustaszewski et al., 2008; Le Breton et al., 2017; Mazzoli and Helman, 1994). We note that in the reconstruction of Mazzoli and Helman (1994), the relative motion vectors of Africa relative to Europe from the Late Oligocene to Middle Miocene shift from NNE-SSW to NNW-SSE, similar to the observed reorientation of shortening directions in the eastern Southern Alps (e.g. Castellarin et al., 1992). This may suggest that the shortening directions in the eastern Southern Alps coincide with large-scale plate motions, a point previously made by Caputo et al. (2010).

\subsection{Kinematic link between shortening along the Giudicarie Belt and sinistral motion along the NGF}

Variations in shortening along strike of the Giudicarie Belt may be attributed to large-scale strain partitioning, especially near the TC-SV fault system (Fig. 12). This system merges with the NGF, thereby transferring differential shortening between domains 1 and 2 to the NGF and contributing to the sinistral offset along the NGF (Figs. 12 and 14). Figure 14 shows a reconstruction from Late Oligocene to present and uses displacement vector triangles for different time slices to show how shortening contributed to the observed sinistral offset along the NGF. During the Late Oligocene to Early Miocene, $18 \mathrm{~km}$ of shortening in domain 1 was transferred to a minimum of $22 \mathrm{~km}$ of motion along the NGF (see displacement vector triangles in Fig. 14). Subsequently, coeval shortening in domains 1 and 2 since the Middle Miocene contributed at least 18 to $25 \mathrm{~km}$ of additional motion along the NGF (Fig. 14). The range of 18 to $25 \mathrm{~km}$ motion along the NGF since the Middle Miocene reflects the uncertainty in minimum shortening estimates in kinematic domains 1 and 2 related to the presence or absence of putative duplexes at depth along profiles 5 and 6 (Figs. 8 and 9; see discussion in Verwater et al., 2021). Combining the estimates of $22 \mathrm{~km}$ of Late Oligocene to Early Miocene sinistral slip and another 18 to $25 \mathrm{~km}$ of Middle Miocene to recent slip on the NGF yields a total of 40 to $47 \mathrm{~km}$ of sinistral offset along this fault since the Late Oligocene. This minimum 40 to $47 \mathrm{~km}$ of Oligocene to Neogene strike-slip displacement along the NGF may be insufficient to solve the question as to whether the observed $75 \mathrm{~km}$ of sinistral displacement on the NGF is exclusively Oligocene, such that the dextral PF would acquire its interpreted straight pre-Oligocene geometry, as discussed above in Sect. 1 (Laubscher, 1991; Schmid and Kissling, 2000; Handy et al., 2015).

We note that some previous workers regard the NGF to have accommodated no more than $30-40 \mathrm{~km}$ of sinistral displacement (Picotti et al., 1995; Castellarin et al., 2006b) or even less ( $15 \mathrm{~km}$, Viola et al., 2001), which is significantly lower than our minimum estimate for displacement on the
NGF. These authors used small-scale markers and only considered motion along parts of the Giudicarie Fault System (the Passeier fault in Viola et al., 2001; the SGF in Castellarin et al., 2006b) or used slightly lower shortening estimates (Picotti et al., 1995). These studies further based their view on Mesozoic paleogeographical variations on either side of the NGF (Castellarin and Vai, 1981; Picotti et al., 1995; Prosser, 1998) that are at a low angle with the NNW-striking, early Mesozoic facies change going from the Trento Plateau to the Lombardian Basin. They interpret this near-linear coincidence as evidence for a pre-Alpine (Mesozoic) offset, thus rendering the map-view offset along the PF to be partly an artefact of Mesozoic rift tectonics. In addition, Müller et al. (2001) estimated a shortening of more than $40 \mathrm{~km}$ based on jumps in metamorphic grade across the NGF, which (if valid) would suggest only $\sim 40 \mathrm{~km}$ of Paleogene dextral motion along the PF and allow a pre-Oligocene offset of the NGF. However, this is incompatible with the interpreted late Paleogene dextral motion on the PF of some 100-150 km (Laubscher, 1991; Schmid and Kissling, 2000), which would have been accommodated by a roughly equivalent amount of the late Paleogene E-W shortening at high angles to the NGF. E-W shortening of such a magnitude along the NGF has not been observed.

\subsection{Transfer of motion along the NGF to the Eastern Alps}

The minimum 40 to $47 \mathrm{~km}$ of sinistral motion on the NGF must have been transferred into the Alpine orogenic lithosphere north of the Pustertal-Gailtal part of the PF and south of the Northern Calcareous Alps. The northern Alpine Front is not offset by an equivalent amount. Therefore, obvious structures to accommodate this displacement are in the Tauern Window, as already proposed by numerous authors (e.g. Laubscher, 1991; Frisch et al., 1998; Linzer et al., 2002; Scharf et al., 2013). Based on 2D map view kinematic reconstructions, Favaro et al. (2017) estimated at least $25 \mathrm{~km}$ of NS Neogene shortening (Fig. 12) associated with kilometrescale upright, post-nappe folding in the Western Tauern Window, located just north of the angular junction of the NGF and PF defining the tip of the eastern Adriatic indenter. This implies that a remaining amount of $\mathrm{N}-\mathrm{S}$ shortening was transferred into orogen-parallel, lateral escape of the Eastern Alps towards the Pannonian Basin (Ratschbacher et al., 1989; Frisch et al., 1998, 2000; Linzer et al., 2002; Rosenberg et al., 2007; Scharf et al., 2013; Handy et al., 2015). Estimates of lateral extrusion vary between $65-77 \mathrm{~km}$ (Favaro et al., 2017) and $160 \mathrm{~km}$ (Frisch et al., 2000). The latter amount is probably an overestimate because the authors assumed that Austroalpine units exposed at the western and eastern ends of the Tauern Window were in contact prior to Neogene extension, effectively neglecting the contribution of kilometrescale post-nappe upright folding to denudation (see discussion in Favaro et al., 2017). The amount of eastward motion 


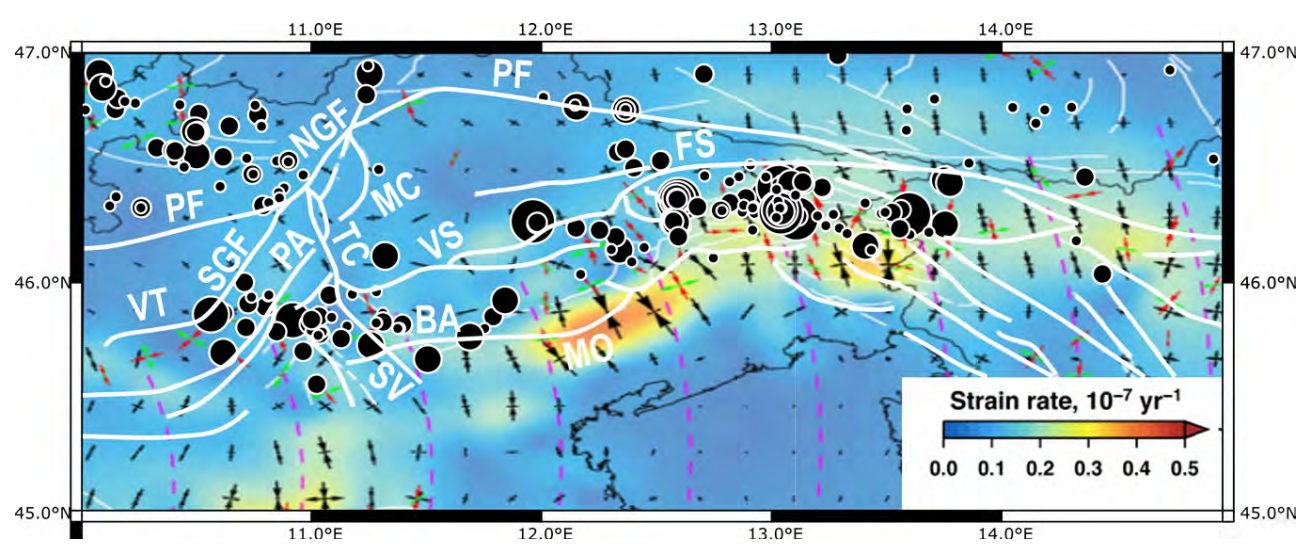

Figure 13. Epicentres of seismic events from 2017-2018 ( $M_{\mathrm{L}} \geq 1$; the size of the black dots indicates earthquake magnitudes up to $M_{\mathrm{L}}$ 4.2) compiled from the SWATH-D Network (Jozi Najafabadi et al., 2021) superposed on strain rates determined from GPS velocities (following Serpelloni et al., 2016). Note that the area in the centre with the highest strain rates (vicinity of the Montello Thrust) coincides with lower seismic activity, although clustering of low-magnitude events has been reported (Moratto et al., 2019; Romano et al., 2019). FS stands for Fella-Sava Fault; see Fig. 1 for the other fault abbreviations.

can be roughly estimated by balancing the amount of shortening within the Southern Alps with shortening within the Tauern Window, although the amount of lateral escape as a function of indentation also depends on the depth of detachment underneath the Tauern Window, which is unknown. Our minimum estimates for Middle Miocene to recent NNWSSE shortening within the Giudicarie Belt $(\sim 25 \mathrm{~km})$ combined with Late Oligocene to Early Miocene NNE-SSW shortening estimates across the Val-Trompia fold-and-thrust belt (Picotti et al., 1995) would suggest less lateral extrusion than the $160 \mathrm{~km}$ proposed by Frisch et al. (2000). We therefore favour the estimate of 65 to $77 \mathrm{~km}$ (Favaro et al., 2017) of E-W-directed, orogen-parallel extension of the Eastern Alps since $21 \mathrm{Ma}$ (Favaro et al., 2017). Assuming that 40 to $47 \mathrm{~km}$ motion along the NGF was transferred to the Tauern Window (Laubscher, 1990) and resulted in $25 \mathrm{~km} \mathrm{~N}-\mathrm{S}$ shortening in the Tauern Window (Favaro et al., 2017), a total of 65 to $72 \mathrm{~km} \mathrm{~N}-\mathrm{S}$ Neogene Alpine shortening can be estimated. This range of shortening estimates is clearly less than Adria-Europe Neogene plate convergence proposed in plate tectonic reconstructions $(\sim 100 \mathrm{~km}$, Van Hinsbergen et al., 2020; 135 km, Le Breton et al., 2017, 2021). This either suggests that the plate tectonic reconstructions are overestimating the Neogene Adria-Europe plate convergence or, alternatively, that additional sources of shortening may have contributed to the overall plate convergence. This discrepancy could be attributed to three possible factors: (1) alternative interpretations of profiles across the Giudicarie Belt (see discussion in Sect. 5.1 and 5.2), (2) "buried" shortening underneath the Po Plain (see discussion in Sect. 5.3), or (3) additional $\mathrm{N}-\mathrm{S}$ shortening associated with upright folding and lateral extrusion rooting in the Tauern Window, possibly associated with an Adriatic crustal wedge, as we discuss in Sect. 6.5 below.

\subsection{Transfer of motion at lower crustal - mantle depths}

The contribution of shortening along the Giudicarie Belt to offset along the NGF requires that the basal detachment of the former roots in the latter. Alternatively, the basal detachment of the Giudicarie Belt and NGF occupy different depths, implying the absence of a kinematic link between shortening along the Giudicarie Belt and motion along the NGF. Additional shortening could be accommodated by a lower crustal Adriatic wedge, which according to reflection seismic studies extends $25 \mathrm{~km}$ north of the PF beneath the Tauern Window (Fig. 12; Gebrande et al., 2002; Lüschen et al., 2004; Castellarin et al., 2006a). This would necessitate decoupling between relatively weak orogenic crust and rigid denser lower Adriatic crust. The shortening associated with this sub-Tauern wedge can be no more than its $25 \mathrm{~km}$ length measured in a $\mathrm{N}-\mathrm{S}$ direction, which is equal or less than the minimum amount of $\mathrm{N}-\mathrm{S}$ shortening in our sections and along other transects of the eastern Southern Alps (Schönborn, 1999; Castellarin and Cantelli, 2000; Nussbaum, 2000). Our results show that along-strike variations in Neogene shortening within the Giudicarie Belt coincide with pre-existing structures, indicating a main detachment horizon exists beneath the Giudicarie Belt. This detachment horizon could either be linked at depth with the NGF, $\mathrm{PF}$, and a lower crustal Adriatic wedge underneath the Eastern Alps (sub-Tauern wedge; Lüschen et al., 2004; Castellarin et al., 2006a) or alternatively could extend northwestward of the NGF and linked with the Adriatic lower crustal wedge beneath the central Alps. We consider the latter hypothesis to be rather unlikely given the wide $\mathrm{E}-\mathrm{W}$ extent of this wedge towards the Western Alps and the modest amount of shortening along the Giudicarie Belt. The Eastern Alpine crustal wedge may be shorter than the lower crustal Adriatic wedge in the Central Alps (Schmid et al., 1996; Rosenberg 

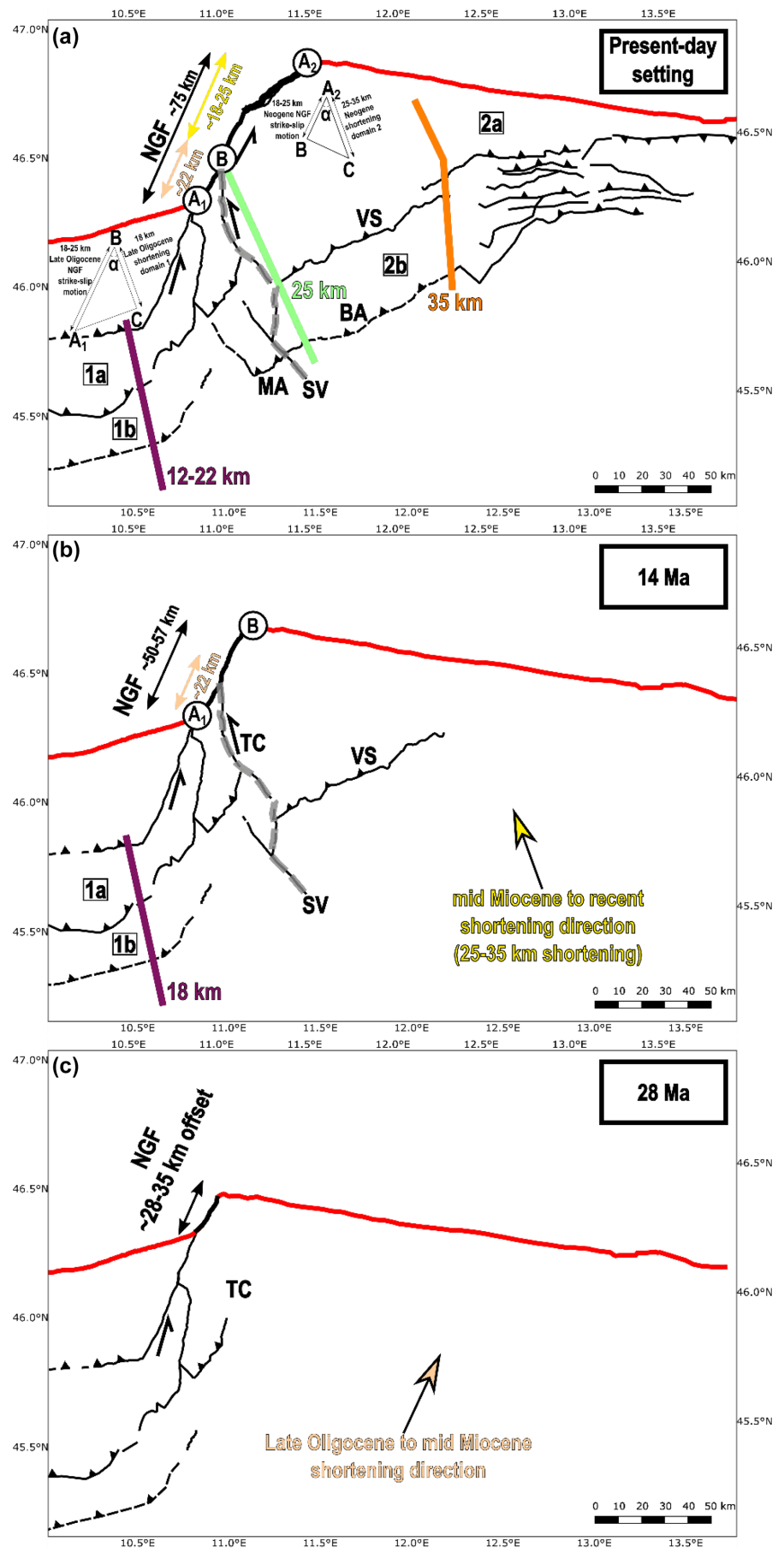

Figure 14. Kinematic evolution of the eastern Southern Alps from the present day (a) to Late Oligocene time (c). (a) Present configuration of the eastern Southern Alps with $\sim 75 \mathrm{~km}$ sinistral offset of the PF along the NGF. There are two kinematic contributions to the $\sim 75 \mathrm{~km}$ of strike-slip motion: (1) 25-35 km of Middle Miocene NNW-SSE shortening across kinematic domain 1 and 2 (Fig. 12), which when projected onto the NGF, corresponds to $\sim 18-25 \mathrm{~km}$ of sinistral strike-slip (displacement vector triangle $\boldsymbol{A}_{2} \boldsymbol{B} \boldsymbol{C}$ ), and (2) $18 \mathrm{~km}$ of Chattian to Middle Miocene, NNE-SSW to NNW-SSE shortening west of the TC-SV fault system, which when projected onto the NGF corresponds to $\sim 22 \mathrm{~km}$ of sinistral strike-slip (see discussion in Sect. 3). (b) At $\sim 14$ Ma the NGF sinistrally displaced the PF by $\sim 50-57 \mathrm{~km}$ (both minimum values). Since the Middle Miocene $(\geq 14 \mathrm{Ma}), \sim 20-35 \mathrm{~km}$ of shortening both east and west of the TC-SV fault system were transferred to motion along the NGF at $\geq 14 \mathrm{Ma}$ which is therefore at this time only displaced by $50-57 \mathrm{~km}$. The minimum $\sim 50-57 \mathrm{~km}$ offset along the NGF at $\sim 14 \mathrm{Ma}$ is partly attributable to a minimum $18 \mathrm{~km}$ of Late Oligocene to Middle Miocene shortening along the Val Trompia-Giudicarie Belt ("kinematic step 1" of Picotti et al., 1995). (c) At $\sim 28$ Ma the Periadriatic Fault was only modestly offset ( 28-35 km). If one assumes a mean value within this range of offsets, the PF restores to a relatively straight fault showing only a minor bend north of the Adamello batholith. 
and Kissling, 2013). Nevertheless, its relationship with Neogene shortening across the eastern Southern Alps remains enigmatic. Possibly, the amount of shortening observed at the surface and within the Adriatic crust is an expression of lateral variations in the strength of the Adriatic upper and lower crust, as also proposed for the Central Alpine lower crustal Adriatic wedge (Rosenberg and Kissling, 2013). To test this hypothesis, future studies using local earthquake tomography are necessary to image and delineate a potential lower Adriatic crustal wedge beneath the Tauern Window and Eastern Alps. Such studies may also constrain the dip of the NGF at depth, which in existing Moho maps does not appear to offset the Moho (e.g. Spada et al., 2013).

Previous studies have also suggested the presence of an Adriatic slab underneath the Eastern Alps (Lippitsch et al., 2003; Handy et al., 2015). Recent seismic tomography studies using the dense AlpArray seismic network indicate, however, that the slab beneath the Eastern Alps is completely detached from the orogenic crust and extends down to (and locally beyond) the $410 \mathrm{~km}$ discontinuity that marks the top of the mantle transition zone (Handy et al., 2021). This slab length is far greater than the $25-50 \mathrm{~km}$ estimates of shortening in the eastern Southern Alps (this study and Schönborn 1999), which represent accreted units of the Adriatic plate. This discrepancy strongly favours a European origin of the slab and effectively rules out an Adriatic origin as proposed in earlier studies (e.g. Lippitsch et al., 2003; Handy et al., 2015).

\section{Conclusion}

This study focuses on constraining its Neogene kinematics and depth of deformation, in particular the kinematic link between shortening in the Giudicarie Belt and motion along the NGF, and their connection to deeper structures. Fault-slip analysis confirms that the main Neogene shortening direction is NNW-SSE. Balancing of seven geological cross sections within the Giudicarie Belt indicates a dominant thick-skinned structural style of deformation, as shown by ramp anticlines exposing the pre-Permian basement in the hanging wall of faults and clustering of recent seismicity at ca. 15 to $20 \mathrm{~km}$ depth within the basement. This thick-skinned tectonic structure implies a modest amount of shortening $(8-25 \mathrm{~km})$ within the studied area. The variations in Neogene shortening coincide with major Permian-Mesozoic paleogeographic domains that divide the studied area into two kinematic domains, west and east of the Trento-Cles-Schio-Vicenza transfer fault system that accommodated about $13 \mathrm{~km}$ of sinistral slip. The lateral variation in shortening reflects competence contrasts and sedimentary thickness variations across the paleogeographic zones. Zones of thickest sedimentary cover, comprising relatively incompetent slope deposits, have accommodated more Neogene shortening $(17-25 \mathrm{~km})$, whereas zones of thinnest sedimen- tary cover, with competent platform carbonates, accommodated the least amount of shortening $(8-12 \mathrm{~km})$.

Projecting the amount of shortening onto the NGF yields a minimum of 40 to $47 \mathrm{~km}$ of sinistral slip along this fault since the Late Oligocene. This amount may be insufficient to fully explain the $75 \mathrm{~km}$ of sinistral offset of the Periadriatic Fault, although a possible additional source of Neogene shortening could be a potential Adriatic lower crustal wedge. Future work using local earthquake tomography is necessary to test this hypothesis and determine its potential lateral extent and relationship to shortening within the upper crust. Here, we follow the interpretation that Adriatic indentation into the Eastern Alps is responsible for most of the $75 \mathrm{~km}$ sinistral offset along the NGF, triggering lateral escape of the Eastern Alps. Furthermore, we interpret the eastward increase of shortening, from 11 to $25 \mathrm{~km}$, within our study area to reflect lateral variations in strength of the Adriatic indenter due to inherited Permian to Mesozoic tectonic structures and paleogeographic zones.

Data availability. All reconstruction and forward modelling files, as well as the complete set of cross sections of this study, are available from the following data repository website: https://doi.org/10. 5880/fidgeo.2021.006 (Verwater et al., 2021).

Author contributions. The project was conceived by MRH, ELB, and $\mathrm{CH}$ as part of the German Research Priority Program (SPP2017) "Mountain Building in 4-Dimensions", an interdisciplinary arm of the European AlpArray Project. Fieldwork, fault-slip analysis, drawing of stratigraphic columns, and construction and balancing of cross sections were performed by VFV under the supervision of ELB and MRH and with the advice of VP. VFV wrote the manuscript with major contributions from ELB and MRH. AJN and $\mathrm{CH}$ provided the earthquake catalogue and participated in the discussion on seismicity and active structural domains of the Southern Alps.

Competing interests. The authors declare that they have no conflict of interest.

Special issue statement. This article is part of the special issue "New insights into the tectonic evolution of the Alps and the adjacent orogens". It is not associated with a conference.

Acknowledgements. We would like to thank Petex for granting the FU Berlin educational licenses of the MOVE suite. This work greatly benefited from stimulating conversations with Philipp Balling, Jan Pleuger, Philip Groß, and Julian Hülscher, as well as a visit in the field with Alfio Viganò (ICAMO-Trento) and discussions with Giuliana Rossi, Alessandro Vuan, and Stefano Parolai at the OGS in Trieste. 
Financial support. This research has been supported by the Deutsche Forschungsgemeinschaft (grant nos. BR 4900/3-1, HA 2403/22-1, and HA 3326/5-1).

Review statement. This paper was edited by Giancarlo Molli and reviewed by Christoph von Hagke and Dario Zampieri.

\section{References}

Anderlini, L., Serpelloni, E., Tolomei, C., De Martini, P. M., Pezzo, G., Gualandi, A., and Spada, G.: New insights into active tectonics and seismogenic potential of the Italian Southern Alps from vertical geodetic velocities, Solid Earth, 11, 1681-1698, https://doi.org/10.5194/se-11-1681-2020, 2020.

Anselmi, M., Govoni, A., De Gori, P., and Chiarabba, C.: Seismicity and velocity structures along the south-Alpine thrust front of the Venetian Alps (NE-Italy), Tectonophysics, 513, 37-48, https://doi.org/10.1016/j.tecto.2011.09.023, 2011.

Avanzini, M., Bargossi, G., Borsato, A., and Selli, L.: Note illustrative della Carta Geologico d'Italia alla scala 1:50000, Foglio 060, Trento, Provincia Autonoma di Trento, Provincia Autonoma di Bolzano, Roma, 2010.

Bartolomei, G., Corsi, M., Dal Cin, R., D’Amico, C., Gatto, G., Gatto, P., Nardin, M., Rossi, D., Sacerdotti, M., and Semenza, E.: Note illustrative della Carta Geologico d'Italia, Foglio 21, Trento, Serv. Geol. d'Italia, Roma, 1969.

Bernoulli, D. and Jenkyns, H.: Alpine, Mediterranean and Central Atlantic Mesozoic Facies in Relation to the Early Evolution of the Tethys, SEPM Special Publication, 19, https://doi.org/10.2110/pec.74.19.0129, 1974.

Bernoulli, D. and Winkler, W.: Heavy mineral assemblages from Upper Cretaceous South- and Austroalpine flysch sequences (northern Italy and southern Switzerland): source terranes and palaeotectonic implications, Eclogae Geol. Helv., 83, 287-310, 1990.

Bertotti, G., Picotti, V., Bernoulli, D., and Castellarin, A.: From rifting to drifting: tectonic evolution of the South-Alpine upper crust from the Triassic to the Early Cretaceous, Sediment. Geol., 86, 53-76, https://doi.org/10.1016/0037-0738(93)90133-P, 1993.

Bosellini, A., Carraro, F., Corsi, M., De Vechi, G., Gatto, G., Malaroda, R., Sturani, C., Ungaro, S., and Zanettin, B.: Note illustrative della Carta Geologico d'Italia, Foglio 49, Verona, Serv. Geol. d'Italia, Roma, 1969.

Boyer, S.: Styles of folding within thrust sheets: examples from the Appalachian and Rocky Mountains of the U.S.A. and Canada, J. Struct. Geol., 8, 325-339, https://doi.org/10.1016/01918141(86)90053-2, 1986.

Brack, P.: Structures in the Southwestern Border of the Adamello Intrusion (Alpi Bresciane, Italy), Schweiz. Miner. Petrog., 61, 37-50, 1981.

Braga, G., Gatto, G., Gatto, P., Gregnanin, A., Massari, F., Medizza, F., and Semenza, E.: Note illustrative della Carta Geologico d'Italia, Foglio 22, Feltre, Serv. Geol. d'Italia, Roma, 1971.

Bressan, G., Ponton, M., Rossi, G., and Urban, S.: Spatial organization of seismicity and fracture pattern in NE Italy and W Slovenia, J. Seismol., 20, 511-534, 2016.
Burrato, P., Poli, M., Vannoli, P., Zanferrari, A., Basili, R., and Galadini, F.: Sources of $M_{\mathrm{W}} 5+$ earthquakes in northeastern Italy and western Slovenia: An updated view based on geological and seismological evidence, Tectonophysics, 453, 157-176, https://doi.org/10.1016/j.tecto.2007.07.009, 2008.

Caputo, R., Poli, M., and Zanferrari, A.: NeogeneQuaternary tectonic stratigraphy of the eastern Southern Alps, NE Italy, J. Struct. Geol., 32, 1009-1027, https://doi.org/10.1016/j.jsg.2010.06.004, 2010.

Castellarin, A. and Cantelli, L.: Neo-Alpine evolution of the Southern Eastern Alps, J. Geodyn., 30, 251-274, https://doi.org/10.1016/S0264-3707(99)00036-8, 2000.

Castellarin, A. and Vai, G.: Importance of Hercynian tectonics within the framework of the Southern Alps, J. Struct. Geol., 3, 477-486, https://doi.org/10.1016/0191-8141(81)90047-X, 1981.

Castellarin, A., Braga, G., Corsi, M., De Vecchi, G., Gatto. G., Gatto, G., Largaiolli, T., Monese, A., Mozzi, G., Rui, A., Sassi, F., and Zirpoli, G.: Note illustrative della Carta Geologico d'Italia, Foglio 36, Schio, Serv. Geol. d'Italia, Roma, 1968.

Castellarin, A., Cantelli, L., Fesce, A., Mercier, J., Picotti, V., Pini, G., Prosser, G., and Selli, L.: Alpine compressional tectonics in the southern Alps: relationships with the N-Apennines, Annales Tectonicae, 6, 62-94, 1992.

Castellarin, A., Picotti, V., Cantelli, L., Claps, M., Trombetta, L., Selli, L., Carton, A., Borsato, A., Daminato, F., Nardin, M., Santuliana, E., Veronese, L., and Bollettinari, G.: Note illustrative della Carta Geologico d'Italia alla scala 1:50000, Foglio 080, Riva Del Garda, Provincia Autonoma di Trento, L.A.C., Firenze, 2005.

Castellarin, A., Nicolich, R., Fantoni, R., Cantelli, L., Sella, M., and Selli, L.: Structure of the lithosphere beneath the Eastern Alps (southern sector of the TRANSALP transect), Tectonophysics, 414, 259-282, https://doi.org/10.1016/j.tecto.2005.10.013, $2006 a$.

Castellarin, A., Vai, G., and Cantelli, L.: The Alpine evolution of the Southern Alps around the Giudicarie faults: A Late Cretaceous to Early Eocene transfer zone, Tectonophysics, 414, 203-223, https://doi.org/10.1016/j.tecto.2005.10.019, 2006b.

Dal Piaz, G.: Sull'esistenza del Pliocene marino nel Veneto, Accademia Scientifica Veneto Istriana, Atti, Vol. 5, 1912.

Dal Piaz, G., Castellarin, A., Martin, S., Selli, L., Carton, A., Pellegrini, G., Casolari, E., Daminato, F., Montresor, L., Picotti, V., Prosser, G., Santuliana, E., and Cantelli, L.: Note illustrative della Carta Geologica d'Italia alla scala 1:50.000, Foglio 042 Malè, 2007.

Delvaux, D. and Sperner, B.: Stress tensor inversion from fault kinematic indicators and focal mechanism data: the TENSOR program, Geol. Soc. Lond. Spec. Publ., 212, 75-100, 2003.

Dewey, J., Helman, M., Knott, S., Turco, E., and Hutton, D.: Kinematics of the western Mediterranean, Geol. Soc. Lond. Spec. Publ., 45, 265-283, https://doi.org/10.1144/GSL.SP.1989.045.01.15, 1989.

Doglioni, C.: Thrust tectonics examples from the Venetian Alps, Studi Geol. Camerti, 117-129, 1990.

Doglioni, C.: The Venetian Alps thrust belt, in: Thrust Tectonics, edited by: McClay, K. R., Springer, Dordrecht, https://doi.org/10.1007/978-94-011-3066-0_29, 1992. 
Doglioni, C. and Bosellini, A.: Eoalpine and Mesoalpine tectonics in the Southern Alps, Geol. Rundsch., 76, 735-754, https://doi.org/10.1007/BF01821061, 1987.

Fantoni, R. and Franciosi, R.: Tectono-sedimentary setting of the Po Plain and Adriatic Foreland, Rendiconti Lincei-scienze Fisiche E Naturali, 21, 197-209, https://doi.org/10.1007/s12210-0100102-4, 2010.

Favaro, S., Schuster, R., Handy, M., Scharf, A., and Pestal, G.: Transition from orogen-perpendicular to orogen-parallel exhumation and cooling during crustal indentation - Key constraints from $147 \mathrm{Sm} / 144 \mathrm{Nd}$ and $87 \mathrm{Rb} / 87 \mathrm{Sr}$ geochronology (Tauern Window, Alps), Tectonophysics, 665, 1-16, https://doi.org/10.1016/j.tecto.2015.08.037, 2015.

Favaro, S., Handy, M., Scharf, A., and Schuster, R.: Changing patterns of exhumation and denudation in front of an advancing crustal indenter, Tauern Window (Eastern Alps), Tectonics, 36, 1053-1071, https://doi.org/10.1002/2016TC004448, 2017.

Fondriest, M., Smith, S., Di Toro, G., Zampieri, D., and Mittempergher, S.: Fault zone structure and seismic slip localization in dolostones, an example from the Southern Alps, Italy, J. Struct. Geol., 45, 52-67, https://doi.org/10.1016/j.jsg.2012.06.014, 2012.

Franceschi, M., Massironi, M., Franceschi, P., and Picotti, V.: Spatial analysis of thickness variability applied to an Early Jurassic carbonate platform in the central Southern Alps (Italy): a tool to unravel syn-sedimentary faulting, Terra Nova, 26, 239-246, https://doi.org/10.1111/ter.12092, 2014.

Frisch, W., Kuhlemann, J., Dunkl, I., and Brügel, A.: Palinspastic reconstruction and topographic evolution of the Eastern Alps during Late Tertiary tectonic extrusion, Tectonophysics, 297, 115, https://doi.org/10.1016/S0040-1951(98)00160-7, 1998.

Frisch, W., Dunkl, I., and Kuhlemann, J.: Post-collisional orogen-parallel large-scale extension in the Eastern Alps, Tectonophysics, 327, 239-265, https://doi.org/10.1016/S00401951(00)00204-3, 2000.

Fügenschuh, B., Seward, D., and Mancktelow, N.: Exhumation in a convergent orogen: The western Tauern window, Terra Nova, 9, 213-217, https://doi.org/10.1111/j.13653121.1997.tb00015.x, 1997.

Fügenschuh, B., Mancktelow, N., and Schmid, S.: Comment on Rosenberg and Garcia: Estimating displacement along the Brenner Fault and orogen-parallel extension in the Eastern Alps, Int. J. Earth Sci. (Geol. Rundsch.) (2011), 100, 1129-1145, Int. J. Earth Sci., 101, https://doi.org/10.1007/s00531-011-0725-4, 2012.

Galadini, F., Poli, M., and Zanferrari, A.: Seismogenic sources potentially responsible for earthquakes with $M>=6$ in the eastern Southern Alps (Thiene-Udine sector, NE Italy), Geophys. J. Int., 161, 739-762, https://doi.org/10.1111/j.1365246X.2005.02571.x, 2005.

Gebrande, H., Luschen, E., Bopp, M., Bleibinhaus, F., Lammerer, B., Oncken, O., Stiller, M., Kummerow, J., Kind, R., Millahn, K., Grassl, H., Neubauer, F., Bertelli, L., Borrini, D., Fantoni, R., Pessina, C., Sella, M., Castellarin, A., Nicolich, R., and Bernabini, M.: First deep seismic images of the Eastern Alps reveal giant crustal wedges and transcrustal ramps, Geophys. Res. Lett., 29, 92.1-92.4, https://doi.org/10.1029/2002GL014911, 2002.

Handy, M.: The structure, age and kinematics of the Pogallo fault zone, southern Alps, northwestern Italy, Eclogae Geol. Helv., 80, 593-632, 1987.
Handy, M. and Zingg, A.: The tectonic and rheological evolution of an attenuated cross section of the continental crust: Ivrea crustal section, southern Alps, northwestern Italy and southern Switzerland, Geol. Soc. Am. Bull., 103, 236-253, https://doi.org/10.1130/00167606(1991)103<0236:TTAREO>2.3.CO;2, 1991.

Handy, M., Babist, J., Wagner, R., Rosenberg, C., and KonradSchmolke, M.: Decoupling and its relation to strain partitioning in continental lithosphere: Insight from the Periadriatic fault system (European Alps), Geol. Soc. Lond. Spec. Publ., 243, 249276, https://doi.org/10.1144/GSL.SP.2005.243.01.17, 2005.

Handy, M., Schmid, S., Bousquet, R., Kissling, E., and Bernoulli, D.: Recoiling plate-tectonic reconstructions of Alpine Tethys with the geological-geophysical record of spreading and subduction in the Alps, Earth-Sci. Rev., 102, 121-158, https://doi.org/10.1016/j.earscirev.2010.06.002, 2010.

Handy, M., Ustaszewski, K., and Kissling, E.: Reconstructing the Alps-Carpathians-Dinarides as a key to understanding switches in subduction polarity, slab gaps and surface motion, Int. J. Earth Sci., 104, 1-26, https://doi.org/10.1007/s00531-014-10603, 2015.

Handy, M., Schmid, S., Paffrath, M., Friederich, W., and the AlpArray Working Group: European tectosphere and slabs beneath the greater Alpine area - Interpretation of mantle structure in the Alps-Apennines-Pannonian region from teleseismic $V_{\mathrm{p}}$ studies, Solid Earth Discuss. [preprint], https://doi.org/10.5194/se-202149, in review, 2021.

Heberer, B., Reverman, R., Fellin, M., Neubauer, F., Dunkl, I., Zattin, M., Seward, D., Genser, J., and Brack, P.: Postcollisional cooling history of the Eastern and Southern Alps and its linkage to Adria indentation, Int. J. Earth Sci., 106, 1557-1580, https://doi.org/10.1007/s00531-016-1367-3, 2016.

Heit, B., Cristiano, L., Haberland, C., Tilmann, F., Pesaresi, D., Jia, Y., Hausmann, H., Hemmleb, S., Haxter, M., Zieke, T., Jaeckl, K.-H., Schloemer, A., and Weber, M.: The Swath-D network in the Eastern Alps, Seismol. Res. Lett., 92, 1592-1609, https://doi.org/10.1785/0220200377, 2021.

Hülscher, J., Sobel, E., Verwater, V., Groß, P., Chew, D., and Bernhardt, A.: Detrital apatite geochemistry and thermochronology from the Oligocene/Miocene Alpine foreland record the early exhumation of the Tauern Window, Basin Res., in review, 2021.

Jozi Najafabadi, A., Haberland, C., Ryberg, T., Verwater, V. F., Le Breton, E., Handy, M. R., Weber, M., and the AlpArray and AlpArray SWATH-D working groups: Relocation of earthquakes in the southern and eastern Alps (Austria, Italy) recorded by the dense, temporary SWATH-D network using a Markov chain Monte Carlo inversion, Solid Earth, 12, 10871109, https://doi.org/10.5194/se-12-1087-2021, 2021.

Karousová, H., Plomerova, J., and Vecsey, L.: Seismic tomography of the upper mantle beneath the north-eastern Bohemian Massif (central Europe), Tectonophysics, 564-565, 111, https://doi.org/10.1016/j.tecto.2012.06.031, 2012.

Kästle, E., Rosenberg, C., Boschi, L., Bellahsen, N., Meier, T., and El-Sharkawy, A.: Slab break-offs in the Alpine subduction zone (Open Access), Int. J. Earth Sci., 109, 587-603, https://doi.org/10.1007/s00531-020-01821-z, 2020.

Keim, L. and Stingl, V.: Lithostratigraphy and facies architecture of the Oligocene conglomerates at Monte Parei (Fanes, 
Dolomites, Italy), Riv. Ital. Paleontol. S., 106, 123-132, https://doi.org/10.13130/2039-4942/5393, 2000.

Laubscher, H.: The problem of the deep structure of the Southern Alps: 3-D material balance considerations and regional consequences, Tectonophysics, 176, 103-121, https://doi.org/10.1016/0040-1951(90)90261-6, 1990.

Laubscher, H.: The arc of the Western Alps today, Eclogae Geol. Helv., 84, 631-659, 1991.

Le Breton, E., Handy, M., Molli, G., And Ustaszewski, K.: Post20 Ma motion of the Adriatic plate - new constraints from surrounding orogens and implications for crust-mantle decoupling: Post-20 Ma motion of the Adriatic plate, Tectonics, 36, 31353154, https://doi.org/10.1002/2016TC004443, 2017.

Le Breton, E., Brune, S., Ustaszewski, K., Zahirovic, S., Seton, M., and Müller, R. D.: Kinematics and extent of the PiemontLiguria Basin - implications for subduction processes in the Alps, Solid Earth, 12, 885-913, https://doi.org/10.5194/se-12885-2021, 2021.

Linzer, H., Decker, K., Peresson, H., Dellmour, R., and Frisch, W.: Balancing lateral orogenic float of the Eastern Alps, Tectonophysics, 354, 211-237, https://doi.org/10.1016/S00401951(02)00337-2, 2002.

Lippitsch, R., Kissling, E., and Ansorge, J.: Upper mantle structure beneath the Alpine orogen from high-resolution teleseismic tomography, J. Geophys. Res., 108, 2376, https://doi.org/10.1029/2002JB002016, 2003.

Luciani, V. and Silvestrini, A.: Planktonic foraminiferal biostratigraphy and paleoclimatology of the Oligocene/Miocene transition from the Monte Brione Formation (Northern Italy, Lake Garda), Mem. Sci. Geol., 48, 155-169, 1996.

Lüschen, E., Lammerer, B., Gebrande, H., Millahn, K., and Nicolich, R.: Orogenic structure of the Eastern Alps, Europe, from TRANSALP deep seismic reflection profiling, Tectonophysics, 388, 85-102, https://doi.org/10.1016/j.tecto.2004.07.024, 2004.

Marrett, R. and Allmendinger, R.: Kinematic analysis of fault-slip data, J. Struct. Geol., 12, 973-986, https://doi.org/10.1016/01918141(90)90093-E, 1990.

Martin, S., Bigazzi, G., Zattin, M., Viola, G., and Balestrieri, M.: Neogene kinematics of the Giudicarie fault (Central-Eastern Alps, Italy): New apatite fission-track data, Terra Nova, 10, $217-$ 221, https://doi.org/10.1046/j.1365-3121.1998.00119.x, 1998.

Massari, F., Grandesso, P., Stefani, C., and Jobstraibizer, P.: A Small Polyhistory Foreland Basin Evolving in a Context of Oblique Convergence: The Venetian Basin (Chattian to Recent, Southern Alps, Italy), Spec. Publs. Int. Ass. Sedim., 8, 141-168, 1986.

Mazzoli, S. and Helman, M.: Neogene patterns of relative plate motion for Africa-Europe: some implications for recent central Mediterranean tectonics, Geol. Rundsch., 83, 464-468, 1994.

Mitterbauer, U., Behm, M., Brückl, E., Lippitsch, R., Guterch, A., Keller, R., Koslovskaya, E., Rumpfhuber, E., and Šumanovac, F.: Shape and origin of the East-Alpine slab constrained by the ALPASS teleseismic model, Tectonophysics, 510, 195-206, https://doi.org/10.1016/j.tecto.2011.07.001, 2011.

Moratto, L., Romano, M., Laurenzano, G., Colombelli, S., Priolo, E., Zollo, A., Saraò, A., and Picozzi, M.: Source parameter analysis of microearthquakes recorded around the underground gas storage in the Montello-Collalto Area (Southeastern Alps, Italy), Tectonophysics, 762, 159-168, https://doi.org/10.1016/j.tecto.2019.04.030, 2019.
Müller, W., Prosser, G., Mancktelow, N., Villa, I., Kelley, S., Viola, G., and Oberli, F.: Geochronological constraints on the evolution of the Periadriatic Fault System (Alps), Int. J. Earth Sci., 90, 623653, https://doi.org/10.1007/s005310000187, 2001.

Nussbaum, C.: Neogene tectonics and thermal maturity of sediments of the easternmost Southern Alps (Friuli area, Italy), PhD thesis, Université de Neuchâtel, Switzerland, 172 pp., 2000.

Oldow, J., Bally, A., and Lallemant, H.: Transpression, orogenic float, and lithospheric balance, Geology, 18, 991-994, https://doi.org/10.1130/00917613(1990)018<0991:TOFALB>2.3.CO;2, 1990.

Ortner, H., Aichholzer, S., Zerlauth, M., Pilser, R., and Fügenschuh, B.: Geometry, amount and sequence of thrusting in the Subalpine Molasse of Western Austria and Southern Germany, European Alps, Tectonics, 34, 1-30, https://doi.org/10.1002/2014TC003550, 2015.

Petersen, G. M., Cesca, S., Heimann, S., Niemz, P., Dahm, T., Kühn, D., Kummerow, J., Plenefisch, T., and the AlpArray Working Group: Regional centroid MT inversion of small to moderate earthquakes in the Alps using the dense AlpArray seismic network: challenges and seismotectonic insights, Solid Earth Discuss. [preprint], https://doi.org/10.5194/se-2021-13, in review, 2021.

Picotti, V. and Cobianchi, M.: Jurassic stratigraphy of the Belluno Basin and Friuli Platform: a perspective on far-field compression in the Adria passive margin, Swiss J. Geosci., 110, 833-850, https://doi.org/10.1007/s00015-017-0280-5, 2017.

Picotti, V., Prosser, G., and Castellarin, A.: Structures and kinematics of the Giudicarie-Val Trompia fold and thrust belt (Central Southern Alps, Northern Italy), Mem. Sci. Geol., 47, 95-109, 1995.

Picotti, V., Casolari, E., Castellarin, A., Mosconi, A., Cairo, E., Pessina, C., and Sella, M.: Alpine inversion of Mesozoic rift basin: the case of the Eastern Lombardian Prealps, AGIPUniversita di Bologna, 1-102, 1997.

Pilli, A., Sapigni, M., and Zuppi, G.: Karstic and alluvial aquifers: A conceptual model for the plain - Prealps system (northeastern Italy), Journal of Hydrology, 464-465, 94-106, https://doi.org/10.1016/j.jhydrol.2012.06.049, 2012.

Pomella, H., Urs, K., Scholger, R., Stipp, M., and Fügenschuh, B.: The Northern Giudicarie and the Meran-Mauls fault (Alps, Northern Italy) in the light of new paleomagnetic and geochronological data from boudinaged Eo-/Oligocene tonalites, Int. J. Earth Sci., 100, 1827-1850, https://doi.org/10.1007/s00531-0100612-4, 2011.

Pomella, H., Stipp, M., and Fügenschuh, B.: Thermochronological record of thrusting and strike-slip faulting along the Giudicarie Fault System (Alps, Northern Italy), Tectonophysics, 579, 118130, https://doi.org/10.1016/j.tecto.2012.04.015, 2012.

Pola, M., Ricciato, A., Fantoni, R., Fabbri, P., and Zampieri, D.: Architecture of the western margin of the North Adriatic foreland: The Schio-Vicenza fault system, Ital. J. Geosci., 133, 223-234, https://doi.org/10.3301/IJG.2014.04, 2014.

Pola, M., Fabbri, P., Piccinini, L., and Zampieri, D.: Conceptual and numerical models of a tectonically-controlled geothermal system: A case study of the Euganean Geothermal System, Northern Italy, Central European Geology, 58, 129-150, https://doi.org/10.1556/24.58.2015.1-2.9, 2015. 
Prosser, G.: Strike-slip movements and thrusting along a transpressive fault zone: The North Giudicarie line (Insubric line, Northern Italy), Tectonics, 17, 921-937, https://doi.org/10.1029/1998TC900010, 1998.

Prosser, G.: The development of the North Giudicarie fault zone (Insubric Line, Northern Italy), J. Geodyn., 30, 229-250, https://doi.org/10.1016/S0264-3707(99)00035-6, 2000.

Qorbani, E., Bianchi, I., and Bokelmann, G.: Slab detachment under the Eastern Alps seen by seismic anisotropy, Earth Planet. Sc. Lett., 409, 96-108, https://doi.org/10.1016/j.epsl.2014.10.049, 2015

Ratschbacher, L., Frisch, W., Neubauer, F., Schmid, S., and Neugebauer, J.: Extension in compressional orogenic belts: The Eastern Alps, Geology, 17, 404-407 https://doi.org/10.1130/00917613(1989)017<0404:EICOBT>2.3.CO;2, 1989.

Ratschbacher, L., Frisch, W., Linzer, H., and Merle, O.: Lateral extrusion in the eastern Alps, Part 2: Structural analysis, Tectonics, 10, 257-271, https://doi.org/10.1029/90TC02623, 1991.

Reverman, R., Fellin, M., Herman, F., Willett, S., and Fitoussi, C.: Climatically versus tectonically forced erosion in the Alps Thermochronometric constraints from the Adamello Complex, Southern Alps, Italy, Earth Planet. Sc. Lett., 339-340, 127-138, https://doi.org/10.1016/j.epsl.2012.04.051, 2012.

Roeder, D.: Thrusting and wedge growth, Southern Alps of Lombardia (Italy), Tectonophysics, 207, 199-243, https://doi.org/10.1016/0040-1951(92)90478-O, 1992.

Romano, M. A., Peruzza, L., Garbin, M., Priolo, E., and Picotti, V.: Microseismic Portrait of the Montello Thrust (Southeastern Alps, Italy) from a Dense High-Quality Seismic Network, Seismol. Res. Lett., 90, 1502-1517, 2019.

Rosenberg, C. and Garcia, S.: Estimating displacement along the Brenner Fault and orogen-parallel extension in the Eastern Alps, Int. J. Earth Sci., 100, 1129-1145, https://doi.org/10.1007/s00531-011-0645-3, 2011

Rosenberg, C. and Kissling, E.: Three-dimensional insight into Central-Alpine collision: Lower-plate or upper-plate indentation?, Geology, 41, 1219-1222, https://doi.org/10.1130/G34584.1, 2013.

Rosenberg, C., Brun, J., Cagnard, F., and Gapais, D.: Oblique indentation in the Eastern Alps: Insights from laboratory experiments, Tectonics, 26, TC2003, https://doi.org/10.1029/2006TC001960, 2007.

Rosenberg, C., Schneider, S., Scharf, A., Bertrand, A., Hammerschmidt, K., Rabaute, A., and Brun, J.: Relating collisional kinematics to exhumation processes in the Eastern Alps, Earth-Sci. Rev., 176, 311-344, https://doi.org/10.1016/j.earscirev.2017.10.013, 2018.

Scharf, A., Handy, M., Favaro, S., Schmid, S., and Bertrand, A.: Modes of orogen-parallel stretching and extensional exhumation in response to microplate indentation and roll-back subduction (Tauern Window, Eastern Alps), Int. J. Earth Sci., 102, 16271654, https://doi.org/10.1007/s00531-013-0894-4, 2013.

Schmid, S. and Kissling, E.: The arc of the Western Alps in the light of new data on deep crustal structure, Tectonics, 19, 62-85, https://doi.org/10.1029/1999TC900057, 2000.

Schmid, S., Pfiffner, O., Kissling, E., Froitzheim, N., and Schönborn, G.: Geophysical-geological transect and tectonic evolution of the Swiss-Italian Alps, Tectonics, 15, 1036-1064, https://doi.org/10.1029/96TC00433, 1996.
Schmid, S., Fügenschuh, B., Kissling, E., and Schuster, R.: Tectonic map and overall architecture of the Alpine orogeny, Eclogae Geol. Helv., 97, 93-117, https://doi.org/10.1007/s00015004-1113-x, 2004.

Schmid, S., Bernoulli, D., Fügenschuh, B., Matenco, L., Schefer, S., Schuster, R., Tischler, M., and Ustaszewski, K.: The Alpine-Carpathian-Dinaridic orogenic system: Correlation and evolution of tectonic units, Swiss J. Geosci., 101, 139-183, https://doi.org/10.1007/s00015-008-1247-3, 2008.

Schmid, S., Scharf, A., Handy, M., and Rosenberg, C.: The Tauern Window (Eastern Alps, Austria): A new tectonic map, with cross-sections and a tectonometamorphic synthesis, Swiss J. Geosci., 106, 1-32, https://doi.org/10.1007/s00015-013-0123-y, 2013.

Schönborn, G.: Kinematics of a transverse zone in the Southern Alps, Italy, in: Thrust Tectonics, edited by: McClay, K. R. Springer, Dordrecht, https://doi.org/10.1007/978-94-011-30660_27, 1992.

Schönborn, G.: Balancing cross sections with kinematic constraints: The Dolomites (northern Italy), Tectonics, 18, 527-545, https://doi.org/10.1029/1998TC900018, 1999.

Selli, L.: Il lineamento della Valsugana fra Trento e Cima d'Asta: cinematica neogenica ed eredità strutturali permo-mesozoiche nel quadro evolutivo del Sudalpino Orientale (NE-Italia), Mem. Soc. Geol. It, 53, 503-541, 1998.

Selli, L., Bargossi, G., Battistini, G., Mordenti, A., Tranne, C., and Stefani, A.: Le vulcaniti permiane a $\mathrm{N}$ della Linea del Calisio: Evoluzione strutturale del margine SW del distretto vulcanico atesino (Trento, Italia), Mineralogica et Petrographica Acta, 39, 169-196, 1996.

Semenza, E.: La fase Giudicariense, nel quadro di una nuova ipotesi sull'Orogenesi Alpina nell' area Italo-Dinarica, Mem. Soc. Geol. It., 13, 187-226, 1974.

Serpelloni, E., Vannucci, G., Anderlini, L., and Bennett, R.: Kinematics, seismotectonics and seismic potential of the eastern sector of the European Alps from GPS and seismic deformation data, Tectonophysics, 688, 157-181, https://doi.org/10.1016/j.tecto.2016.09.026, 2016.

Spada, M., Bianchi, I., Kissling, E., Agostinetti, N., and Wiemer, S.: Combining controlled-source seismology and receiver function information to derive 3-D Moho topography for Italy, Geophys. J. Int., 194, 1050-1068, https://doi.org/10.1093/gji/ggt148, 2013.

Stipp, M., Fügenschuh, B., Gromet, L., Stünitz, H., and Schmid, S.: Contemporaneous plutonism and strike-slip faulting: A case study from the Tonale fault zone north of the Adamello pluton (Italian Alps), Tectonics, 23, TC3004, https://doi.org/10.1029/2003TC001515, 2004.

Suppe, J.: Geometry and Kinematics of Fault-bend Folding, Am. J. Sci., 283, 684-721, 1983.

Tapponnier, P., Peltzer, G., and Armijo, R.: On the mechanics of the collision between India and Asia, Geological Society, Lond. Spec. Publ., 19, 113-157, https://doi.org/10.1144/GSL.SP.1986.019.01.07, 1986.

Thöny, W., Ortner, H., and Scholger, R.: Paleomagnetic evidence for large en-bloc rotations in the Eastern Alps during Neogene orogeny, Tectonophysics, 414, 169-189, https://doi.org/10.1016/j.tecto.2005.10.021, 2006.

Ustaszewski, K., Schmid, S., Fügenschuh, B., Tischler, M. Kissling, E., and Spakman, W.: A map-view restoration of 
the Alpine-Carpathian-Dinaridic system for the Early Miocene, Swiss J. Geosci., 101, 273-294, https://doi.org/10.1007/s00015008-1288-7, 2008.

Van Hinsbergen, D., Torsvik, T., Schmid, S., Maţenco, L., Maffione, M., Vissers, R., Gürer, D., and Spakman, W.: Orogenic architecture of the Mediterranean region and kinematic reconstruction of its tectonic evolution since the Triassic, Gondwana Res., 81, 79-229, https://doi.org/10.1016/j.gr.2019.07.009, 2020.

Verwater, V. F., Le Breton, E., Handy, M. R., Picotti, V., Jozi Najafabadi, A., and Haberland, C.: Balanced cross sections along the Giudicarie Belt (Southern Alps, Northern Italy) in 3-D Move, GFZ Data Services [data set], https://doi.org/10.5880/fidgeo.2021.006, 2021.

Viganò, A., Scafidi, D., Ranalli, G., Martin, S., Vedova, B. D., and Spallarossa, D.: Earthquake relocations, crustal rheology, and active deformation in the central-eastern Alps (N Italy), Tectonophysics, 661, 81-98, 2015.

Viganò, A., Zampieri, D., Rossato, S., Martin, S., Selli, L., Prosser, G., Ivy-Ochs, S., Campedel, P., Fedrizzi, F., Franceschi, M., and Rigo, M.: Past to present deformation of the central-eastern Southern Alps: from the foreland to the Giudicarie belt, Geological Field Trips and Maps, 10, 1-78, https://doi.org/10.3301/GFT.2018.01, 2018.
Viola, G., Mancktelow, N., and Seward, D.: Late OligoceneNeogene evolution of Europe-Adria collision: New structural and geochronological evidence from the Giudicarie fault system (Italian Eastern Alps), Tectonics, 20, 999-1020, https://doi.org/10.1029/2001TC900021, 2001.

Von Hagke, C., Cederbom, C., Oncken, O., Stockli, D., Rahn, M., and Schlunegger, F.: Linking the Northern Alps with Their Foreland: the Latest Exhumation History Resolved by Low-Temperature Thermochronology, Tectonics, 31, TC5010, https://doi.org/10.1029/2011TC003078, 2012.

Winterer, E. and Bosellini, A.: Subsidence and sedimentation on Jurassic passive continental margin, Southern Alps, Italy, AAPG Bull., 65, 394-421, 1981.

Zampieri, D.: Tertiary extension in the Southern Trento Platform, Southern Alps, Italy, Tectonics, 14, 645-657, https://doi.org/10.1029/94TC03093, 1995.

Zampieri, D., Massironi, M., Sedea, R., and Sparacino, V.: Strikeslip contractional stepovers in the Southern Alps (Northeastern Italy), Eclogae Geol. Helv., 96, 115-123, 2003.

Zampieri, D., Vannoli, P., and Burrato, P.: Geodynamic and seismotectonic model of a long-lived transverse structure: The SchioVicenza Fault System (NE Italy), Solid Earth Discuss. [preprint], https://doi.org/10.5194/se-2021-29, in review, 2021. 